\title{
In situ oxygen dynamics and carbon turnover in an intertidal sediment (Skallingen, Denmark)
}

\author{
Eva Walpersdorf ${ }^{1}$, Michael Kühl ${ }^{2,3}$, Bo Elberling ${ }^{1}$, Thorbjørn J. Andersen ${ }^{1}$, \\ Birger U. Hansen ${ }^{1}$, Morten Pejrup ${ }^{1}$, Ronnie N. Glud ${ }^{4,5,6, *}$ \\ ${ }^{1}$ Department of Geosciences and Natural Resource Management, University of Copenhagen, Øster Voldgade 10, \\ 1350 Copenhagen $K$, Denmark \\ ${ }^{2}$ Marine Biological Laboratory, University of Copenhagen, Strandpromenaden 5, 3000 Helsingør, Denmark \\ ${ }^{3}$ Plant Functional Biology and Climate Change Cluster, University of Technology Sydney, Ultimo, NSW 2007, Australia \\ ${ }^{4}$ University of Southern Denmark, Institute of Biology and Nordic Center for Earth Evolution (NordCEE), Odense M, Denmark \\ ${ }^{5}$ Department of Ocean and Environmental Sciences, Tokyo University of Marine Science and Technology, 4-5-7 Konan, \\ Minato-ku, Tokyo 108-8477, Japan \\ ${ }^{6}$ Scottish Association for Marine Science, Dunstaffnage Marine Laboratory, PA37 1QA Dunbeg, UK
}

\begin{abstract}
Intertidal areas are considered to be productive habitats, but due to the challenging and dynamic environment, in situ assessments of their performance remain scarce. Here, we aimed to quantify the production and turnover of organic material in an intertidal sediment across several consecutive diel/tidal cycles and to evaluate the importance of key drivers affecting the community performance. Time-series measurements of the oxygen $\left(\mathrm{O}_{2}\right)$ microdistribution across 2 sites at a silty sandflat documented extreme variability, which was mainly driven by light availability and flow conditions. Diffusion dominated the interstitial solute transport, but advective porewater transport was observed during $15 \%$ of the $9 \mathrm{~d}$ study period. Photosynthetic activity never exhibited light inhibition and average daytime net photosynthesis ranged between 1.01 and $11.15 \mathrm{mmol} \mathrm{m}^{-2} \mathrm{~d}^{-1}$ depending on the daily light availability, while the assessed gross primary production was $\sim 80 \%$ higher. When irradiance exceeded $17.2 \mathrm{~mol}$ photons $\mathrm{m}^{-2} \mathrm{~d}^{-1}$, daytime net autotrophy more than balanced the heterotrophic activity during the night (average night-time respiration, $\mathrm{ER}_{\mathrm{n}}$ : $-4.01 \mathrm{mmol} \mathrm{m}^{-2} \mathrm{~d}^{-1}$ ). However, despite intense primary production, the integrated activity during the target autumn period was net heterotrophic with an average net ecosystem metabolism of -2.21 (span: -7.93 to 1.48 ) $\mathrm{mmol} \mathrm{O}_{2} \mathrm{~m}^{-2} \mathrm{~d}^{-1}$. This study highlights the extreme temporal and spatial variation of intertidal sediments and the importance of accounting for natural in situ dynamics to correctly assess their performance and contribution to system production.
\end{abstract}

KEY WORDS: In situ $\mathrm{O}_{2}$ dynamics - Transecting microprofiler - Benthic primary production · $P / E$ relation $\cdot$ Flow $\cdot$ Net ecosystem metabolism $\cdot$ Intertidal

\section{INTRODUCTION}

Sand- and mudflats represent productive transition zones at the land-sea interphase and provide important ecosystem services (Lotze et al. 2005, Reise 2005). In both settings, microphytobenthos (MPB) are the key primary producers and their activity regulates a range of biogeochemical processes and func-

${ }^{*}$ Corresponding author: rnglud@biology.sdu.dk tions (Cammen 1991, Middelburg et al. 2000, Sundbäck et al. 2000). This includes modulating $\mathrm{O}_{2}$ availability, the sediment redox status, and sediment stability and permeability through production of exopolymeric substances (Paterson 1989, Andersen et al. 2010), which are all factors that influence rates and pathways for nutrient regeneration and carbon turnover (De Wit et al. 1989, Risgaard-Petersen 2003, Bar-

(C) The authors 2017. Open Access under Creative Commons by Attribution Licence. Use, distribution and reproduction are unrestricted. Authors and original publication must be credited. 
toli et al. 2003). However, intertidal sediments are also very dynamic due to highly fluctuating environmental conditions, where inundation, light, temperature, salinity, and particle redistribution can change on timescales of minutes to months depending on diurnal, tidal, and seasonal cycles. In high-energy coastal settings, tidal sediments are dominated by sand and advective porewater transport that facilitate efficient biocatalytic transformation of trapped organic material (Ehrenhauss \& Huettel 2004, Ehrenhauss et al. 2004, Cook et al. 2007, Anschutz et al. 2009). In more protected areas, the tidal flats are dominated by diffusion-controlled silty sediments with high carbon content.

A major challenge working in these complex heterogeneous and dynamic environments is to determine primary production and respiration without altering the environmental controls. Reliable measurements have to account for spatial and temporal variations in light, temperature, inundation, hydrodynamics, and biological factors that are all responding to phase-shifted diel and tidal cycles. Most studies quantifying the carbon turnover of intertidal flats have employed sediment enclosure approaches that are bound to affect many of the controls regulating benthic activity, and which have difficulties in capturing the activity over complete tidal cycles (e.g. Spilmont et al. 2007, Migné et al. 2009). Therefore, carbon budgets for intertidal environments are often based on measurements conducted under artificial settings without accounting for natural variability. Only few integrative and non-invasive in situ studies of intertidal sediments have been conducted in either highly permeable sands (e.g. de Beer et al. 2005, Werner et al. 2006) or in muddy sediments (Denis \& Desreumaux 2009, Denis et al. 2012). But even these detailed investigations have only partly been able to determine the metabolic state of their respective settings, and it is still not clear whether intertidal sediments are sources or sinks for $\mathrm{CO}_{2}$ (e.g. Cook et al. 2004, Klaassen \& Spilmont 2012). In the present study, we applied an autonomous transecting profiling instrument equipped with an array of microelectrodes to quantify the in situ microscale $\mathrm{O}_{2}$ distribution in silty sandflats over a series of consecutive diel and tidal cycles. This approach enabled us to quantify benthic activity during concurrent ambient changes in inundation, light availability, temperature, flow conditions, and bed level. The data were used to non-invasively quantify the production and mineralization of organic material at in situ conditions, and to evaluate the relative importance of key controls for the benthic $\mathrm{O}_{2}$ dynamics of intertidal silty sands. Findings are discussed in the context of available studies on carbon turnover in temperate intertidal sediments.

\section{MATERIALS AND METHODS}

\section{Study site and sediment characteristics}

The investigations were carried out from 26 September to 4 October 2007 (autumn) on an intertidal sandflat in the northern part of the Danish Wadden Sea in the shelter of the Skallingen barrier spit

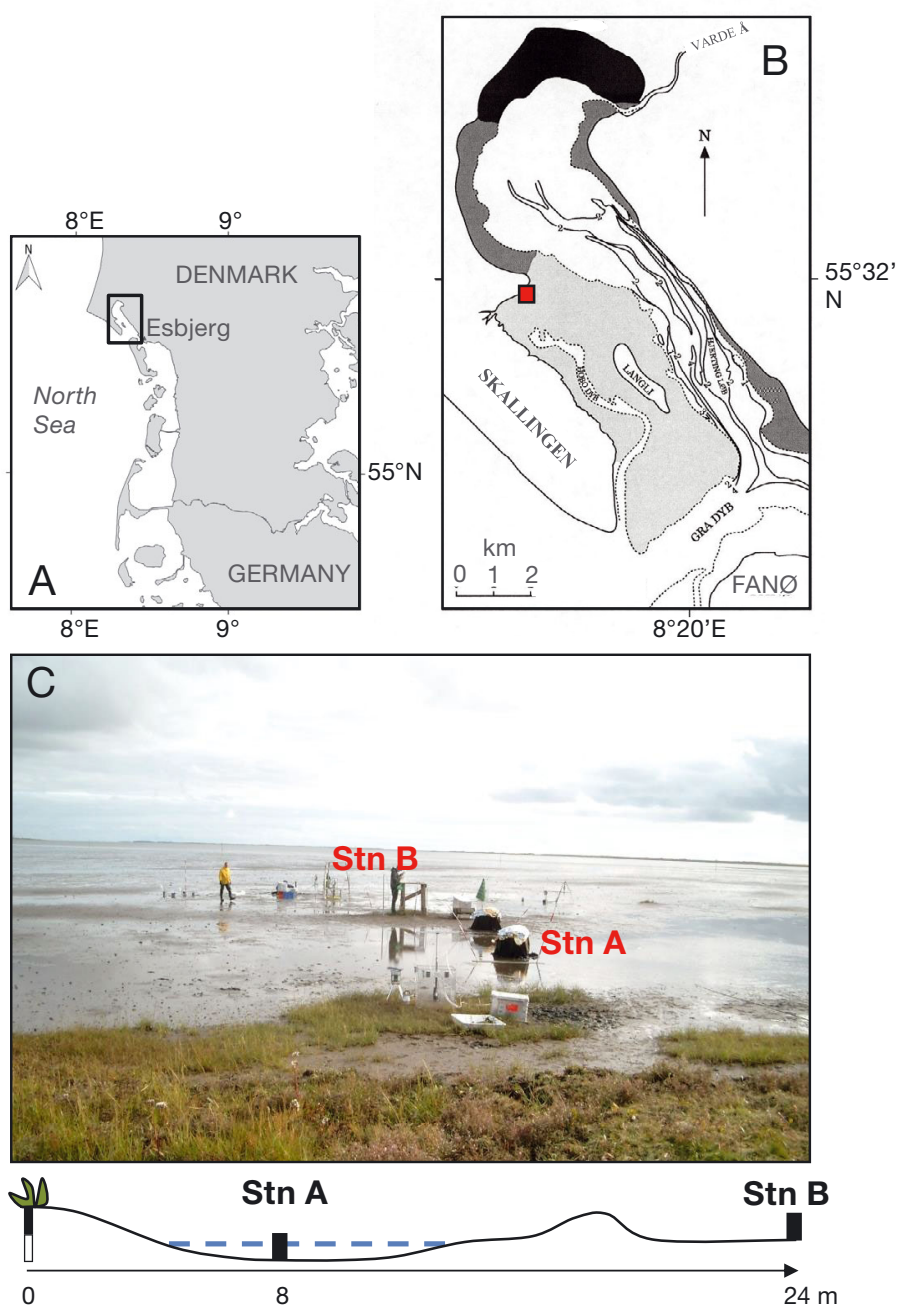

Fig. 1. (A,B) Study area (from Andersen 2001) showing the presence of mud flats (black), mixed mud flats (dark grey), sand flats (light grey) and the position of the field site (red square) at low tide. (C) The transect off the coast with 2 main measurement locations: Stn A, 32U 0453592, 6154129 (UTM coordinate system) and Stn B (with profiler and acoustic Doppler velocimeter [ADV]), 0453609, 6154099. Stn A remains water covered during low tide (blue horizontal line indicates the water level at low tide) 
(Fig. 1). Freshwater input from the river Varde resulted in salinity variations between 23 and 30 at high tide. The area is microtidal, and maximum water depths ranged between 0.3 and $0.9 \mathrm{~m}$ depending on tidal stage and wind impact. Inundation time varied between 3.5 and $7 \mathrm{~h}$, but even during low tide the surface sediment remained water-saturated and covered with a thin layer of water. A climate station was set up to provide data on local weather conditions. Irradiation at the site was recorded from the afternoon of 1 October onwards throughout the field measurements, while irradiance data for the preceding period were taken from a nearby climate station $(15 \mathrm{~km})$. The recorded downwelling short-wave irradiance (in $\mathrm{W} \mathrm{m}^{-2}$ ) was converted into photosynthetically active radiation $\left(\mathrm{PAR}_{;} 400\right.$ to $\left.700 \mathrm{~nm}\right)$ in units of $\mu$ mol photons $\mathrm{m}^{-2} \mathrm{~s}^{-1}$ by calibration against parallel light measurements taken with a light meter (LI-250; LiCor) equipped with an underwater photon irradiance sensor (Li 192A; LiCor) positioned at the sediment surface. Measurements were conducted at 2 locations, 8 and $24 \mathrm{~m}$ from the marsh edge (Stn A: $32 \mathrm{U}$ 0453592, 6154129 and Stn B: 32U 0453609, 6154099; UTM coordinate system) to assess any potential mesoscale difference in sediment performance. The sediment at both stations consisted of slightly muddy ( $5 \%$ silt and clay), fine to medium well-sorted silicate sand grains with a mean grain size (geometric mean, method of moments) of 194 to $271 \mu \mathrm{m}$ in the upper $15 \mathrm{~cm}$ (determined using forward laser scattering by use of a Malvern Mastersizer/E, 1 core, $10 \mathrm{~cm}$ diameter). A total of 2 cores station ${ }^{-1}(3.6 \mathrm{~cm}$ diameter) were taken for the determination of porosity and total organic carbon (TOC). Porosity was calculated from the weight loss of wet sediment after drying and the measured sediment density. Sediment permeability was not measured during the campaign, but the site was revisited in August 2010 and sediment permeability was quantified by the constant head approach (Klute \& Dirksen1986) and amounted to (mean $\pm \mathrm{SD}) 1.0 \times 10^{-12} \pm 2.5 \times 10^{-13} \mathrm{~m}^{2}(\mathrm{n}=3)$ and 3.8 $\times 10^{-12} \pm 6.3 \times 10^{-13} \mathrm{~m}^{2}(\mathrm{n}=3)$ at Stns A and $\mathrm{B}$, respectively. The sediments were therefore characterized by relatively low permeability (Forster et al. 2003).

Sediments for the analysis of TOC were freezedried, ground, and acidified with $1 \mathrm{~mol} \mathrm{l}^{-1} \mathrm{HCl}$ to remove inorganic carbon. Subsequently, TOC was determined in sediment washed and dried at $105^{\circ} \mathrm{C}$ using a LECO TruSpec carbon nitrogen determinator. Samples for chlorophyll a (chl a) were taken with cutoff syringes (1.9 and $2.8 \mathrm{~cm}$ inner diameter), sliced immediately in the field and stored frozen until analysis. Chl a was determined by extraction in $96 \%$ ethanol for $24 \mathrm{~h}$ and spectrophotometry (Biochrom Libra S12) at 665 and $750 \mathrm{~nm}$ and again 2 to $3 \mathrm{~min}$ after acidification with $1 \mathrm{~mol} \mathrm{l}^{-1} \mathrm{HCl}$ to degrade all chlorophyll into phaeopigments. Chl $a$ and phaeopigment content was calculated according to Lorenzen (1967). Macrofauna present in the upper $10 \mathrm{~cm}$ of the sediment was sampled in a $10 \mathrm{~cm}$ diameter core at each site to give a qualitative impression of the community composition only. The fauna, retained on a $500 \mu \mathrm{m}$ sieve, was dominated by Hydrobia ulvae and nematodes, but at Stn A small juvenile polychaetes (Nereis sp. and Scolelepis sp.) and a few bivalves (Macoma sp.) of variable sizes were also observed. Sediment characteristics are summarized in Table 1.

\section{Hydrodynamics and bed level change}

The 3-dimensional (3D) flow velocity at Stn B was measured in a $0.25 \mathrm{~cm}^{3}$ water volume situated $6.5 \mathrm{~cm}$ above the bed by a SonTek/YSI $10 \mathrm{MHz}$ acoustic Doppler velocimeter (ADV) at $10 \mathrm{~Hz}$; average data from periods of $30 \mathrm{~s}$ were stored every $10 \mathrm{~min}$. Water depth, salinity, temperature, and turbidity were measured with an Aanderaa RCM9 current meter with sensors placed $10 \mathrm{~cm}$ above the bed.

Table 1. Selected sediment characteristics of the study site. Numbers represent single determinations (grain size) or the average of 2 measurements; standard deviation is given for chl a

\begin{tabular}{|c|c|c|c|}
\hline & $\begin{array}{c}\text { Depth } \\
\text { (cm) }\end{array}$ & $\begin{array}{c}\text { Stn } \\
\text { A }\end{array}$ & $\begin{array}{c}\text { Stn } \\
\text { B }\end{array}$ \\
\hline Mean grain size ${ }^{a}(\mu \mathrm{m})$ & $0-1$ & 208 & 194 \\
\hline Mud (\%) & & 4.5 & 4.6 \\
\hline Porosity & $\begin{array}{l}0-0.5 \\
0.5-1\end{array}$ & $\begin{array}{l}0.48 \\
0.52\end{array}$ & $\begin{array}{l}0.46 \\
0.41\end{array}$ \\
\hline $\mathrm{TOC}^{\mathrm{b}}(\%)$ & $\begin{array}{l}0-0.5 \\
0.5-1\end{array}$ & $\begin{array}{l}0.20 \\
0.18\end{array}$ & $\begin{array}{l}0.13 \\
0.11\end{array}$ \\
\hline \multirow[t]{2}{*}{ Chlorophyll a $\left(\mu \mathrm{g} \mathrm{g}^{-1}\right)$} & $0-0.2$ & $14.4^{\mathrm{c}}$ & $\begin{array}{c}17.7 \pm 2.5 \\
(\mathrm{n}=7)\end{array}$ \\
\hline & $0.2-0.4$ & $12.2^{\mathrm{c}}$ & $\begin{array}{c}16.0 \pm 1.2 \\
(\mathrm{n}=7)\end{array}$ \\
\hline Hydrobia ulvae (ind. $\mathrm{m}^{-2}$ ) & $0-10$ & 1020 & 382 \\
\hline Nereis sp. (ind. $\mathrm{m}^{-2}$ ) & $0-10$ & 1150 & 0 \\
\hline Scolelepis sp. (ind. $\mathrm{m}^{-2}$ ) & $0-10$ & 255 & 0 \\
\hline Nematodes (ind. $\mathrm{m}^{-2}$ ) & $0-10$ & 16100 & 7670 \\
\hline \multicolumn{4}{|c|}{$\begin{array}{l}{ }^{\mathrm{a}} \text { Geometric mean as calculated by the method of } \\
\text { moments } \\
\text { b Total organic carbon, salt free dry weight } \\
{ }^{\mathrm{c}} 114-117 \mathrm{mg} \mathrm{chl} \mathrm{a} \mathrm{m}^{-2}(\text { range, } \mathrm{n}=2) \text { in total contained in } \\
\text { the upper } 4 \mathrm{~mm} \text { at } \mathrm{Stn} \mathrm{A}\end{array}$} \\
\hline
\end{tabular}




\section{In situ sensor measurements of dissolved oxygen}

In situ measurements of $\mathrm{O}_{2}$ concentration versus depth profiles in the sediment were done with a transecting microprofiler (Glud et al. 2009a). The instrument was placed on the tidal flat during low tide with the microsensors initially positioned 0.5 to $1 \mathrm{~cm}$ above the sediment surface. The profiling module was equipped with 2 or $3 \mathrm{O}_{2}$ sensors and a custom-made 2-wire resistivity sensor $(1 \mathrm{~mm}$ tip diameter) for detection of the sediment surface position. The $\mathrm{O}_{2}$ sensors were Clark-type microsensors (Revsbech 1989) with a sensing tip diameter of $\sim 10 \mu \mathrm{m}$, a $t_{90}$ (the time it takes for the sensor signal to reach $90 \%$ of the final value) response time of $<2 \mathrm{~s}$, and a stirring sensitivity $<2 \%$ (Gundersen et al. 1995). The microsensor response was linearly calibrated from sensor readings in the overlying water (sampled over the duration of the inundation period), and in the anoxic part of the sediment. Dissolved $\mathrm{O}_{2}$ concentration in the ambient seawater was determined on-site by Winkler titration (Grasshoff et al. 1999). Vertical profiling into the sediment was performed in steps of $200 \mu \mathrm{m}$ covering a total distance of $2 \mathrm{~cm}$; at each depth, the signals were logged. After the profiler had moved the microsensor tips back to the start position above the sediment surface and prior to the next measurement, a motor moved the sledge with the instrument horizontally $7 \mathrm{~mm}$ prior to the next set of profile measurements. This distance eliminated any potential oxygenation and other artefacts from holes created during previous measurements and thus allowed undisturbed depth profiles of $\mathrm{O}_{2}$. Each set of $\mathrm{O}_{2}$ depth profiles was recorded within $20 \mathrm{~min}$ with a programmed resting time of $2 \mathrm{~min}$ prior to the next profiling event. These measurements were conducted during deployment times of 14 to $24 \mathrm{~h}$, yielding up to 60 profiles sensor ${ }^{-1}$ covering a total lateral distance of maximally $47.5 \mathrm{~cm}$; the distance between the individual $\mathrm{O}_{2}$ microsensors was 2 to $4 \mathrm{~cm}$. The temperature at the position of the microprofiler was recorded in air and in the surface sediment $(+1,-1$, $-2,-5 \mathrm{~cm}$ ) using Tinytag data loggers and zero-off calibrated thermistor probes. Data were recorded every $30 \mathrm{~s}$ during the deployments.

During low tide, additional $\mathrm{O}_{2}$ microprofiles were measured manually to complement the automated profiling lander measurements. For these measurements, the microsensors were positioned by use of a manually operated micromanipulator (MM33; Märzhäuser), while the sensor signal was read from a picoammeter (PA2000; Unisense).

\section{Modelling of diffusive $\mathrm{O}_{2}$ exchange}

Diffusive $\mathrm{O}_{2}$ fluxes in the sediment were calculated from complete in situ profiles measured under quasi steady-state conditions using the software package PROFILE (Berg et al. 1998). This procedure was preferred rather than the more usual approach based on the concentration gradient within (or just below) the diffusive boundary layer (Jørgensen \& Revsbech 1985) due to the relatively coarse resolution at which the profiles were obtained. The relative position of the sediment surface for the respective profiles was identified from a distinct break in the slope of the concentration profile (Glud et al. 1995). The profile analysis software calculates the rate of net production or consumption as a function of depth together with the flux across the sediment-water interface. The procedure is based on a control volume approach of equally spaced zones, and uses a series of least square fits to adapt the model to the measured concentration profile, followed by comparisons of these fits through statistical F-testing. This enables selection of the simplest production-consumption profile that best reproduces the measured concentration profile. Boundary conditions chosen for diffusive transport modelling were the $\mathrm{O}_{2}$ concentration and flux at the bottom of the calculation domain. Sediment diffusivity $\left(D_{\mathrm{s}}\right)$ was assumed constant with depth and was calculated as: $D_{\mathrm{s}}=D /(1+3[1-\varphi])$ (Iversen \& Jørgensen 1993), where $D$ is the molecular diffusion coefficient of $\mathrm{O}_{2}$ in water corrected for in situ temperature and salinity (Li \& Gregory 1974) and $\varphi$ is the porosity of the surface sediment (Table 1). For the iteration of finding the best fits, maximum deviation when accepting a calculated minimum was set to $0.001 \%$, the level of significance (p-value) used in the $F$-statistics was 0.01 . Daylight $\mathrm{O}_{2}$ production was calculated from a production/light $(P / E)$ relationship established for the entire study period according to the formula $P=P_{\max }\left\{1-\left[\exp \left(-\alpha E / P_{\max }\right)\right]\right\}+R$ (Platt et al. 1980), where $P=$ net production (in $\mathrm{mmol} \mathrm{m}^{-2}$ $\left.\mathrm{d}^{-1}\right), P_{\max }=$ photosynthetic capacity (in $\mathrm{mmol} \mathrm{O}_{2} \mathrm{~m}^{-2}$ $\left.\mathrm{d}^{-1}\right), \alpha=$ initial slope of net production at subsaturating light levels, $E=$ incident light at the sediment surface (in $\mu$ mol photons $\mathrm{m}^{-2} \mathrm{~s}^{-1}$ ), $R=$ dark flux (in mmol $\left.\mathrm{O}_{2} \mathrm{~m}^{-2} \mathrm{~d}^{-1}\right)$.

\section{Light penetration depth}

Light measurements in the sediment were performed with a fiber-optic scalar irradiance microprobe with a small diffusing/light-scattering sphere $(<100 \mu \mathrm{m}$ dia- 
meter) cast at the tapered tip (Rickelt et al. 2016). The microprobe was coupled to a custom-built fiber-optic light meter measuring PAR (400 to $700 \mathrm{~nm}$ ) (Kühl et al. 1997). The linear detector response was calibrated using the sensor signal in seawater at known downwelling irradiance and in darkness.

Light profiles within the sediment were measured in the laboratory on subsamples of water-saturated surface sediment from the site. A fiber-optic tungsten halogen lamp equipped with a collimating lens (Schott KL-2500; $3100 \mathrm{~K}$ ) illuminated the sediment sample vertically from above, while the scalar irradiance microprobe was mounted in a motorized micromanipulator (Unisense) and was inserted into the sediment at an angle of $40^{\circ}$ relative to the incident light to prevent self-shading. Motor control and recording of the sensor readings was performed using the software package Profix (PyroScience). A total of 3 to 4 profiles down to $4.2 \mathrm{~mm}$ depth were measured in each sample at a depth resolution of $200 \mu \mathrm{m}$, with $5 \mathrm{~s}$ waiting time at each depth and signal integration over $1 \mathrm{~s}$.

The attenuation coefficient for photon scalar irradiance, $K_{0}(\mathrm{PAR})$, within the photic zone was calculated as: $K_{0}(\mathrm{PAR})=-\mathrm{d}\left[\ln E_{0}(\mathrm{PAR})\right] / \mathrm{d} z$, where $z$ is depth, by a linear regression on ln-transformed data over the respective linear depth interval (Kühl 2005).

\section{RESULTS}

\section{Benthic oxygen dynamics and regulating factors}

Time-series of microprofiles covering $>76 \mathrm{~h}$ and 7 tidal cycles demonstrated an extensive spatio-temporal variation in the sediment $\mathrm{O}_{2}$ distribution (Figs. 2 \& 3). Parallel sensor measurements reflected the same overall pattern, but also revealed microscale patchiness (Figs. 2 \& 3).

The prime factor affecting benthic $\mathrm{O}_{2}$ distribution was light availability. The sediment surface exhibited a light dependent $\mathrm{O}_{2}$ production and the $\mathrm{O}_{2}$ concentration occasionally reached values up to $\sim 950 \mathrm{\mu mol} \mathrm{l}^{-1}$ (3.0 times air saturation) during mid-day flood tide. This activity enhanced the $\mathrm{O}_{2}$ concentrations in the overlying water up to $\sim 340 \mathrm{\mu mol}^{-1}$ ( 120\% air saturation). However, $\mathrm{O}_{2}$ concentrations as high as $\sim 650 \mu \mathrm{mol}$ $\mathrm{I}^{-1} \mathrm{O}_{2}(\sim 230 \%$ air saturation) were encountered in the overlying water during low tide, when the sediment was covered by a layer of $\sim 1-2 \mathrm{~cm}$ of almost stagnant water. During the night, respiration and re-oxidation processes reduced the thickness of the oxic zone, and the $\mathrm{O}_{2}$ concentration in the overlying water declined to $\sim 200 \mu \mathrm{mol}^{-1}$ ( $70 \%$ air saturation). Beside this overall pattern, short-term variations in solar irradiance due to changing cloud cover quickly led to changes in the $\mathrm{O}_{2}$ distribution within the sediment. For instance, the maximum $\mathrm{O}_{2}$ porewater concentration at high tide during the afternoon of 29 September declined by $\sim 300 \mathrm{mmol}^{-1}$ within $22 \mathrm{~min}$ in response to dense cloud cover, which reduced the ambient irradiance at the sediment surface from 930 to $340 \mu \mathrm{mol}$ photons $\mathrm{m}^{-2} \mathrm{~d}^{-1}$ (Figs. 2 \& 3C). An example of the opposite dynamic was observed at Stn A on 3 October during low tide, when the $\mathrm{O}_{2}$ concentration of the overlying water increased by $\sim 200 \mathrm{\mu moll}^{-1}$ within 22 min as ambient lightlevels increased from 190 to $280 \mu$ mol photons $\mathrm{m}^{-2} \mathrm{~d}^{-1}$ (Fig. 2).

While the salinity-induced changes in $\mathrm{O}_{2}$ solubility were small, temperature variation affected the $\mathrm{O}_{2}$ availability. During the study period, temperatures at the sediment-water interface varied between 9.6 and $17.1^{\circ} \mathrm{C}$, which roughly corresponds to a solubility driven change in $\mathrm{O}_{2}$ concentration of $40 \mu \mathrm{mol} \mathrm{l}^{-1}$ at saturation. Generally, minimum and maximum temperatures were reached at ebb-tide, but variation during a single tidal cycle only led to a maximum solubility driven change of $20 \mu \mathrm{mol} \mathrm{O}_{2} \mathrm{l}^{-1}$. Thus, maximally 3 to $20 \%$ of the observed change in dissolved $\mathrm{O}_{2}$ concentration could be attributed to salinity or temperature-induced changes in $\mathrm{O}_{2}$ solubility.

Apart from light and temperature, other physical factors also affected the benthic $\mathrm{O}_{2}$ distribution and concentration. Despite low $\mathrm{O}_{2}$ concentration at the sediment surface during night-time, these periods also reflected the deepest $\mathrm{O}_{2}$ penetration depth (OPD) (Figs. 2 \& 3B). Such apparently counter-intuitive observations were caused by transient tide-induced advective flow and hydraulic-driven percolation of water through the surface sediments, especially at night when the diatom coverage typically becomes less distinct due to downward cell migration (de Brouwer \& Stal 2001, Du et al. 2010). This most likely enhanced the permeability of the sediment surface during night-time, as observed in other studies (e.g. Westall \& Rincé 1994, Cahoon 1999, Paterson \& Hagerthey 2001). During such periods, the benthic $\mathrm{O}_{2}$ availability appeared to be strongly affected by the ambient average flow (Fig. 4). In these instances, convection could have contributed to the observed porewater mixing, but we have no direct means to assess this potential effect. Suspension of the fluffy sediment material was only observed occasionally, and then just as the rising tide reached the study area or during periods where flow exceeded $0.1 \mathrm{~m} \mathrm{~s}^{-1}$ (Fig. 4). In parallel with the microsensor measurements, the ADV continuously recorded the relative position of the bed 

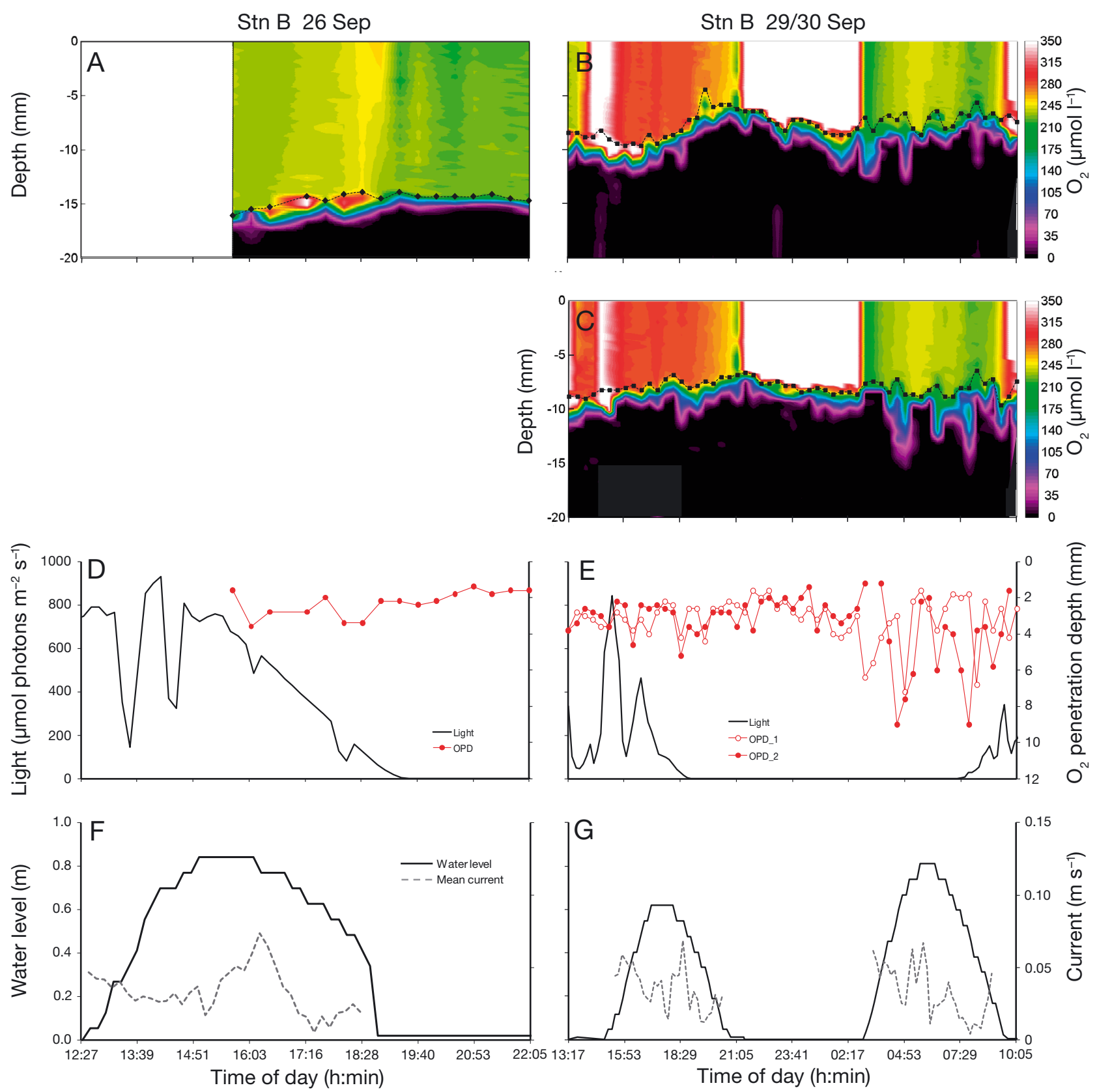

Fig. 2 (continued on next page). Temporal variation in $\mathrm{O}_{2}$ distribution at the sediment-water interphase monitored at 4 time intervals. At one occasion, only 1 sensor was deployed (A), while the other measurements were done with 2 parallel sensors $\left(B, C_{i} H_{1}, J_{i}\right.$ and $\left.\mathrm{I}, \mathrm{K}\right)$. Concurrent measurements of light availability and $\mathrm{O}_{2}$ penetration in the sediment are shown in $(\mathrm{D}, \mathrm{E}, \mathrm{L}, \mathrm{M})$, while $(\mathrm{F}, \mathrm{G}, \mathrm{N}, \mathrm{O})$ show water levels and current speed at the measuring site. Note differences in scale

level at a given location with a precision of $\pm 1 \mathrm{~mm}$. In general, bed levels were constant, but in a few incidences we observed a stepwise shift of 1 or $2 \mathrm{~mm}$ which also was reflected in rapid $\mathrm{O}_{2}$ changes as induced by microscale sedimentation and erosion (Fig. 2). Fauna-induced advective $\mathrm{O}_{2}$ transport as expressed by subsurface maxima or abrupt erratic fluctuations in the $\mathrm{O}_{2}$ concentration distribution during profiling (Glud et al. 2003, Jørgensen et al. 2005, de
Beer et al. 2005) was occasionally observed (Figs. 2 \& $3 \mathrm{D})$. Based on this, we estimated that only $3 \%$ of the microprofiles were affected by macrofauna activity.

Diffusion was the prevailing interstitial transport mode in the targeted silty sands as judged by the fact that most of the time the obtained microprofiles could be modelled by PROFILE using pure diffusive interstitial solute transport (Fig. $3 ; \mathrm{R}^{2} \geq 0.99$ ). As evaluated from the entire data set, these conditions prevailed 

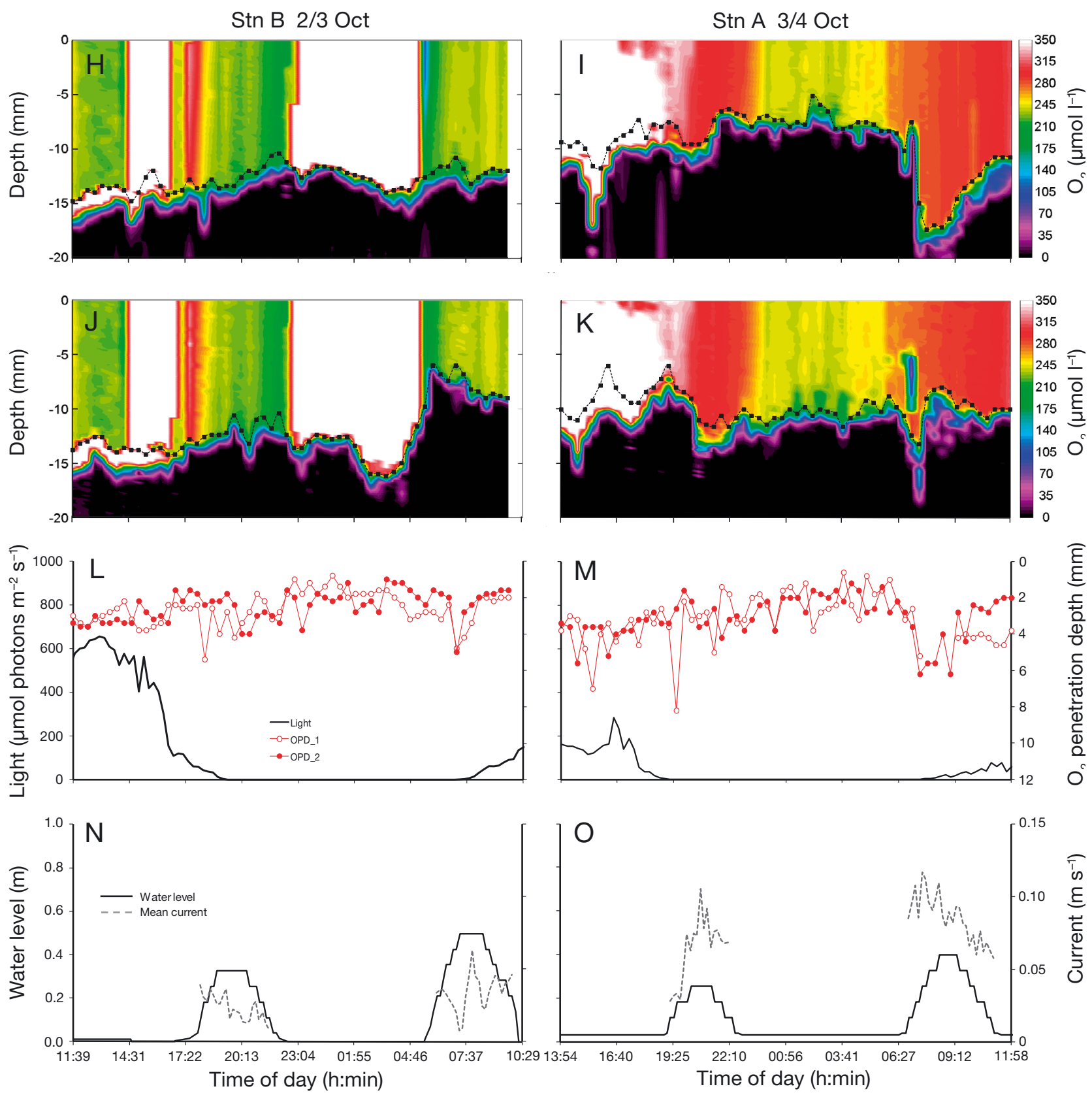

Fig. 2 (continued)

$85 \%$ of the time. Advection only contributed to the benthic $\mathrm{O}_{2}$ dynamics during periods of intense drainage and higher flow velocities (Figs. 3B \& 4). Fig. 4 depicts the typical response to increased bottom water flow, with the significant increase in OPD only visible during high tide periods under dark or very low-light conditions when average current increased $\left(>0.05 \mathrm{~m} \mathrm{~s}^{-1}\right)$ due to elevated wind speeds $\left(>7 \mathrm{~m} \mathrm{~s}^{-1}\right)$.

During the study period, the sediment was always water-saturated and vertical PAR attenuation measured in the laboratory was well described with a mono-exponential attenuation function using a $K_{0}(\mathrm{PAR})$ value of $-2.19 \mathrm{~mm}^{-1}\left( \pm 0.04, \mathrm{R}^{2}=0.99\right)$. Maximum light penetration $(<0.01 \%$ of surface irradiance) was $4.2 \mathrm{~mm}$ under maximal incident irradiance levels of $\sim 750 \mu \mathrm{mol}$ photons $\mathrm{m}^{-2} \mathrm{~s}^{-1}$. However, scalar irradiance at the sediment surface increased to $\sim 930 \mu \mathrm{mol}$ photons $\mathrm{m}^{-2} \mathrm{~s}^{-1}$ due to intense light scattering in the sand grains (Fig. 3C). Applying the minimum and maximum in situ irradiance measurements during our campaign with the $K_{0}$ value found in the laboratory measurements, we calculated photic zone thickness (defined as the depth where only $1 \%$ of 
A

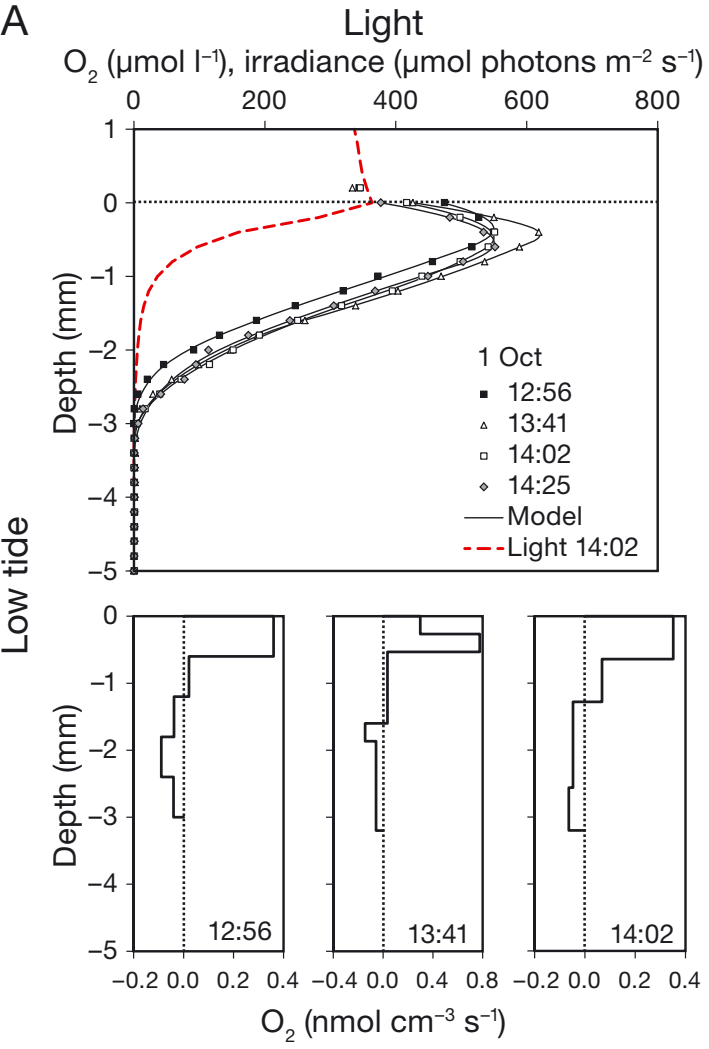

C $\mathrm{O}_{2}\left(\mu \mathrm{mol} \mathrm{I}^{-1}\right)$, irradiance $\left(\mu \mathrm{mol}\right.$ photons $\left.\mathrm{m}^{-2} \mathrm{~s}^{-1}\right)$

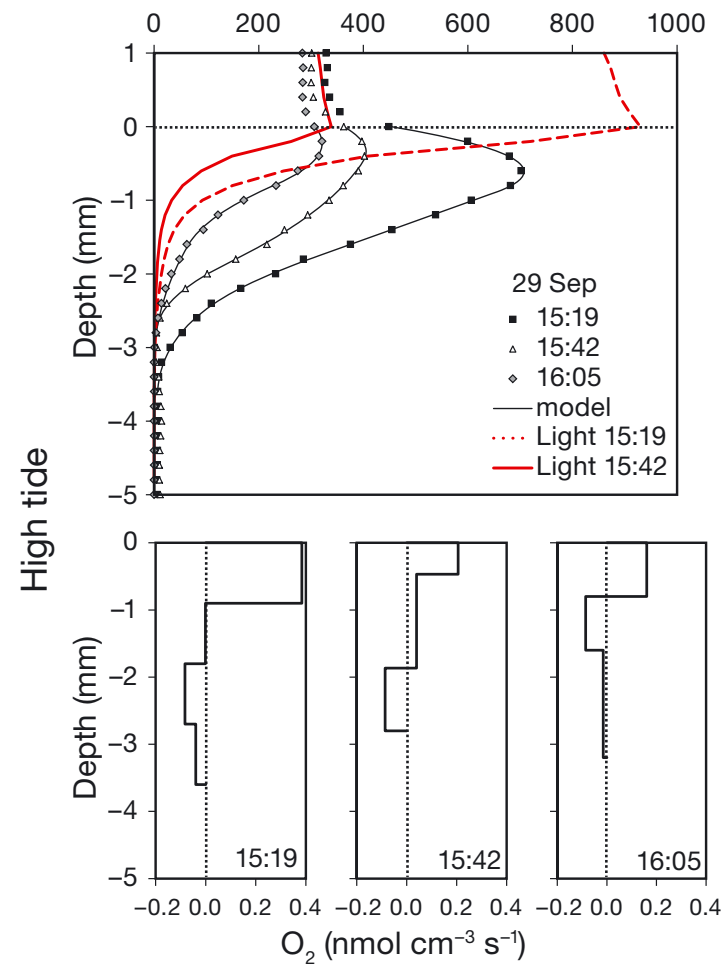

\section{B Darkness}

$\mathrm{O}_{2}\left(\mu \mathrm{mol} \mathrm{I}^{-1}\right)$
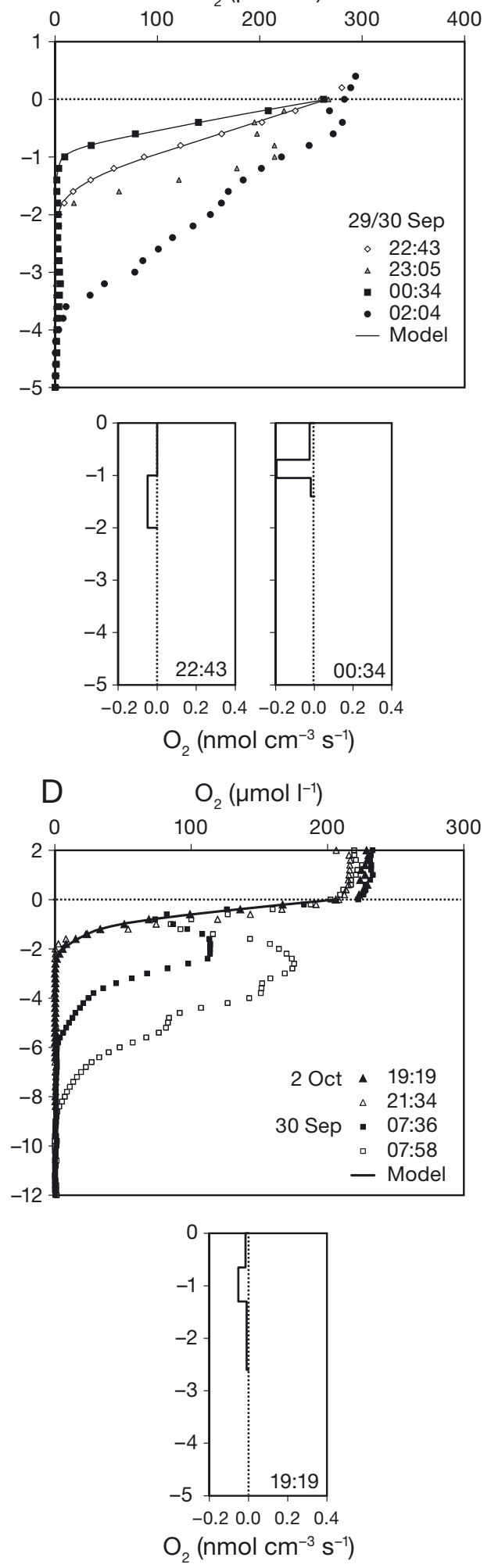

Fig. 3. Characteristic $\mathrm{O}_{2}$ depth distribution at the main study site during $(A, B)$ low tide and $(C, D)$ high tide at different times of the day and different light availability. $(\mathrm{B}, \mathrm{D})$ Night-time profiles showed the occurrence of hydraulic percolation (B), advection or fauna ventilation (D) increasing the $\mathrm{O}_{2}$ penetration considerably. Volumetric production and consumption rates of $\mathrm{O}_{2}$ during periods of diffusive solute transport were modelled using PROFILE (Berg et al. 1998) $\left(\mathrm{R}^{2} \geq 0.99\right)$ 


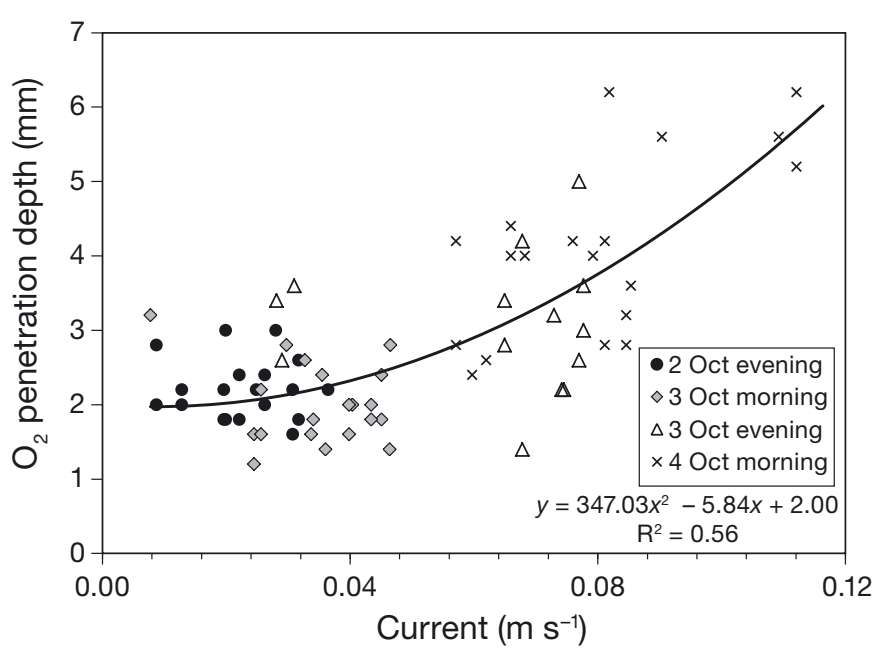

Fig. 4. Measured $\mathrm{O}_{2}$ penetration depth as a function of mean current speed for 2 calm (2 October, morning; 3 October, evening) and 2 rough periods (3 October, evening; 4 October, morning) when current speeds exceeded $0.1 \mathrm{~m} \mathrm{~s}^{-1}$ and maximum velocities (not shown) reached $0.3 \mathrm{~m} \mathrm{~s}^{-1}$, at which point the sediment began to be unstable. Two macrofaunaimpacted and 1 very disturbed profile (3 October, evening) were omitted from the analysis. Values represent measured $\mathrm{O}_{2}$ penetration depths with 2 sensors during high tide at night or low irradiance levels $<100 \mu \mathrm{mol}$ photons $\mathrm{m}^{-2} \mathrm{~s}^{-1}$ (and mostly below the sediment compensation irradiance $\mathrm{CCP}=45 \mu \mathrm{mol}$ photons $\mathrm{m}^{-2} \mathrm{~s}^{-1}$ )

surface irradiance remained) to vary from 0.9 to $3.3 \mathrm{~mm}$ during daytime. This corresponded well to the zone of net-photosynthesis modelled by PROFILE assuming diffusive conditions, where these modelled values ranged between 0.5 and $3.0 \mathrm{~mm}$ with an average value of $1.3 \pm 0.5 \mathrm{~mm}(\mathrm{n}=80)$. Chl a levels of the surface sediment were relatively high, reaching values of $14.4 \mu \mathrm{g} \mathrm{chl} \mathrm{a} \mathrm{g}^{-1}$ at Stn A and 17.7 $\pm 2.5 \mu \mathrm{g} \mathrm{chl} \mathrm{a}$ $\mathrm{g}^{-1}($ mean $\pm \mathrm{SD})$ at $\mathrm{Stn} B(\mathrm{n}=7)$ (Table 1$)$, and did not vary significantly during the investigation period. These relatively high values are consistent with the high phototrophic activity, but clearly the sedimentary chl a content does not necessarily reflect active MPB biomass.

\section{Autotrophic activity in the surface sediment}

The depth-integrated net $\mathrm{O}_{2}$ production modelled from concentration profiles measured under different irradiance levels during the investigation period exhibited a typical saturation curve that could be approximated with a hyperbolic tangent function assuming no photoinhibition (Platt et al. 1980, Fig. 5). Microprofiles obtained manually and by the transecting lander showed very similar results, indicating

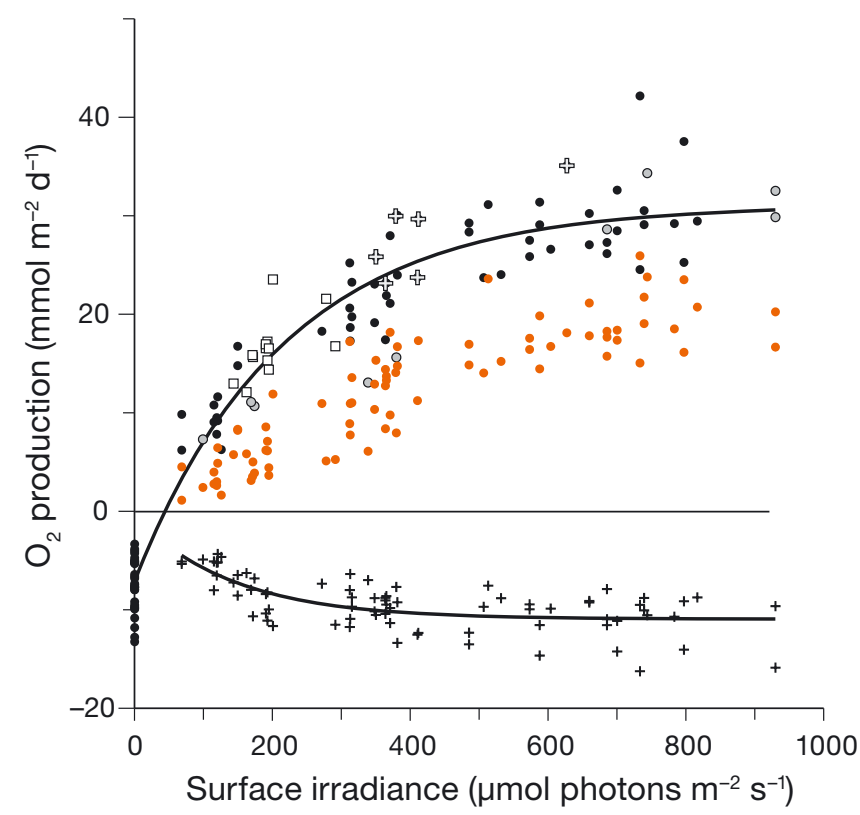

Fig. 5. Diffusive $\mathrm{O}_{2}$ exchange, modelled from 109 in situ $\mathrm{O}_{2}$ concentration profiles, as a function of downwelling irradiance fitted using the function: $P$ (net primary production) $=$ $P_{\max }\left\{1-\left[\exp \left(-\alpha E / P_{\max }\right)\right]\right\}+R$ (Platt et al. 1980), with $P_{\max }$ (photsynthetic capacity) $=38.3 \mathrm{mmol} \mathrm{O}_{2} \mathrm{~m}^{-2} \mathrm{~d}^{-1}, \alpha$ (initial slope at subsaturating light levels) $=0.177 \mathrm{mmol} \mathrm{O}_{2} \mathrm{~m}^{-2} \mathrm{~d}^{-1}$ [ $\mu \mathrm{mol}$ photons $\left.\mathrm{m}^{-2} \mathrm{~s}^{-1}\right]^{-1}$ and $R=-7.12 \mathrm{mmol} \mathrm{O}_{2} \mathrm{~m}^{-2} \mathrm{~d}^{-1}\left(\mathrm{R}^{2}=\right.$ $0.95 ; \mathrm{n}=109$ ). Black (grey) circles: low (high) tide production calculated from microprofile measurements at Stn $B_{\text {; }}$ white crosses: manually recorded profiles; white squares: low tide measurements at the water-covered $\mathrm{Stn} \mathrm{A}_{\text {; }}$ orange circles: net $\mathrm{O}_{2}$ exchange at the primary interphase; black crosses: daytime $\mathrm{O}_{2}$ consumption $\left(\mathrm{ER}_{\mathrm{d}}\right)$ below the photic zone. The trend-line is produced by: $\mathrm{ER}_{\mathrm{d}}=-\left[\left[\mathrm{ER}_{\mathrm{d}-\max }\{1-[\exp (-\alpha E /\right.\right.$ $\left.\left.\left.\left.\left.E_{\mathrm{d}-\max }\right)\right]\right\}+\mathrm{R}\right]\right]$, where $\mathrm{ER}_{\mathrm{d}-\max }=10.5 \mathrm{mmol} \mathrm{m}^{-2} \mathrm{~d}^{-1}, \alpha=0.073$ and $R=0.487 \mathrm{mmol} \mathrm{m}^{-2} \mathrm{~d}^{-1}\left(\mathrm{R}^{2}=0.44 ; \mathrm{n}=75\right)$

that the instrument did not affect the local microenvironment. There was no difference between data obtained at the 2 stations or at different tides, and thus data were compiled for further analysis (Fig. 5). Photosynthesis continued during high tide under calm conditions and a clear water column. Migration of activity zones (net primary production, NPP) was not indicated by consecutive in situ microprofile measurements during daytime. This indicates that potential vertical migration of MPB during daytime was minor. The compensation irradiance for the depth-integrated net photosynthesis at which the system shifts from heterotroph to autotroph (community compensation point, CCP) was $45 \mu \mathrm{mol}$ photons $\mathrm{m}^{-2} \mathrm{~s}^{-1}$, while $P_{\max }$ was $38 \mathrm{mmol} \mathrm{O}_{2} \mathrm{~m}^{-2} \mathrm{~d}^{-1}$, and the irradiance at onset of saturation $\left(P_{\max } / \alpha\right)$ equalled $220 \mu \mathrm{mol}$ photons $\mathrm{m}^{-2} \mathrm{~s}^{-1}$. Analysis of 80 concentration profiles showing oxygen production indicated that, on average, $55 \%$ of the produced $\mathrm{O}_{2}$ was 
released to the overlying water, while $45 \%$ was consumed in the deeper sediment layers (Fig. 5).

The average $\mathrm{O}_{2}$ consumption in deeper sediment layers was clearly stimulated by photosynthesis at the sediment surface, as reflected by the volume-specific $\mathrm{O}_{2}$ consumption rate $\left(R_{\mathrm{v}}\right)$ modelled for 109 in situ microprofiles using PROFILE (Fig. 6). For instance, $R_{\mathrm{v}}$ increased by up to $\sim 200 \%$ in the depth interval between 0.1 and $0.2 \mathrm{~mm}$ during daytime. The strongest increase was observed just below the average depth of the photic zone, and activity was in the same order of magnitude as consumption rates in the upper $\mathrm{mm}$ of the sediment in darkness. This indicates high microbial activity and re-oxidation of reduced endproducts of anaerobic carbon degradation at the oxic-anoxic interface.

In darkness, $R_{\mathrm{v}}$ varied between -0.024 and $-0.079 \mathrm{nmol} \mathrm{O}_{2} \mathrm{~cm}^{-3} \mathrm{~s}^{-1}$ with maximal values at the sediment surface. During daytime, the values for the deeper oxic sediment layers varied between -0.044 and $-0.072 \mathrm{nmol} \mathrm{O}_{2} \mathrm{~cm}^{-3} \mathrm{~s}^{-1}$ with the lowest activity levels encountered in the deepest parts of the concentration profiles. The error bars indicate a high lateral variability of $R_{\mathrm{v}}$. Assuming that the average $\mathrm{O}_{2}$ consumption rate derived for the surface layers during periods where diffusion prevailed is similar to the $\mathrm{O}_{2}$ consumption rate in deeper layers that are occasionally oxygenated by large-scale physical advection, we can estimate the importance of advection for $\mathrm{O}_{2}$ consumption. In general, advection extended the oxic volume of the non-photic sediment by $153 \%$. However, periods of advection/percolation only oc-

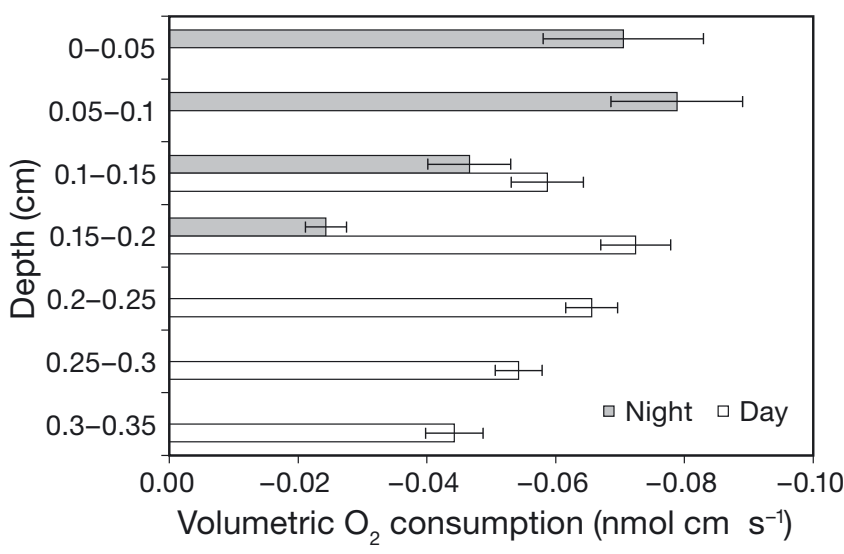

Fig. 6. Weighted average volumetric $\mathrm{O}_{2}$ consumption rates $\left(R_{\mathrm{v}}\right)$ in the surface sediment $\left(\mathrm{nmol} \mathrm{cm} \mathrm{cm}^{-3} \mathrm{~s}^{-1}\right)$ including consumption rates from 80 daytime (white bars) and 29 nighttime profiles (grey bars). The modelled $R_{\mathrm{V}}$ in light only included the sections below sediment layers that exhibited net production, while rates in darkness included the entire oxic zone. Error bars: SE ( $n=22$ to 104) curred during $15 \%$ of the measuring time, and mainly at night. Consequently, the estimated advective-driven $\mathrm{O}_{2}$ uptake calculated with an average night-time $R_{\mathrm{v}}$ of $-0.055 \mathrm{nmol} \mathrm{O}_{2} \mathrm{~cm}^{-3} \mathrm{~s}^{-1}$ and an extension of the oxic zone by $\sim 3.1 \mathrm{~mm}$ only accounted for a daily average of $-2.08(-1.33$ to -3.76$) \mathrm{mmol} \mathrm{m}^{-2}$ $\mathrm{d}^{-1}$ or $22 \%$ of the integrated daily net $\mathrm{O}_{2}$ consumption for the study period (Table 2).

\section{DISCUSSION}

Benthic diatoms are regarded as significant primary producers of intertidal ecosystems (MacIntyre et al. 1996, Underwood \& Kromkamp 1999) yet quantitative in situ estimates of their importance in natural dynamic settings are few (Billerbeck et al. 2007, Denis \& Desreumaux 2009, Denis et al. 2012). By applying a transecting profiling instrument, we were able to monitor in situ sediment $\mathrm{O}_{2}$ dynamics and environmental effects on benthic primary production in intertidal fine-sand sediments during a $9 \mathrm{~d}$ period. These data enable a discussion on carbon turnover in natural and dynamic settings of a microtidal system and the assessment of the key factors regulating the activity.

\section{Effect of advective flow and fauna on $\mathrm{O}_{2}$ dynamics}

Low-energy conditions prevailed during our investigations, which is typical for the targeted area that is characterized by relatively fine-grained sediments with a fluffy layer of muddy fine sand at the surface (Vinther et al. 2004). Despite relatively low sediment permeability $\left(1.0 \times 10^{-12}\right.$ to $\left.3.8 \times 10^{-12} \mathrm{~m}^{2}\right)$ and prevailing diffusive solute transport in the interstitial porewaters, advective porewater transport was observed when current speeds exceeded $0.05 \mathrm{~m} \mathrm{~s}^{-1}$ (Fig. 4). In one instance (4 October, Stn A), the wind speed reached $>12 \mathrm{~m} \mathrm{~s}^{-1}$ and the average flow velocity increased to $0.1 \mathrm{~m} \mathrm{~s}^{-1}$ during incoming tide. This induced persistent advective porewater transport and rising concentrations of suspended matter in the overlying water from 26 to $77 \mathrm{mg} \mathrm{l}^{-1}$. During this period, the $\mathrm{O}_{2}$ penetration depth increased by $105 \%$ to an average $( \pm \mathrm{SD})$ of $4.1 \pm 1.2 \mathrm{~mm}$, leading to a $158 \%$ increase in the $\mathrm{O}_{2}$ consumption rate for a period of $4.8 \mathrm{~h}$. Integrated over the daily period, this event alone increased total net $\mathrm{O}_{2}$ consumption for this day by $23 \%$. During the study period, advective porewater transport occurred $15 \%$ of the time. If we include activities in zones occasionally oxygenated by advection/ 
Table 2. Daily irradiance, light hours (h) with a light intensity above the community compensation point $(\mathrm{CCP})$, diffusive $\mathrm{O}_{2}$ exchange $\left(\mathrm{ER}_{\mathrm{n}}\right.$ : night-time respiration, $\mathrm{ER}_{\mathrm{d}}$ : daytime respiration below the photic zone, NPP and GPP: net and gross primary production during light hours, advection/percolation and NEM: net ecosystem metabolism per $24 \mathrm{~h}$ during a period of consolidation. Fluxes were calculated for every minute of each day of the field campaign in September and October 2007 using a hyperbolic tangent function fitted to the production vs. irradiance curve. For further reference, times of peak ebb and flood tide and maximum water level during inundation are included

\begin{tabular}{|c|c|c|c|c|c|c|c|c|c|c|c|c|}
\hline $\begin{array}{l}\text { Date } \\
(\mathrm{dd} / \mathrm{mm})\end{array}$ & $\begin{array}{c}\text { Irradian } \\
\text { Mol photons } \\
\left(\mathrm{m}^{-2} \mathrm{~d}^{-1}\right)\end{array}$ & $\begin{array}{l}\mathrm{ce}-\overline{\text { Light }} \\
\text { (h) }\end{array}$ & $\underset{\text { (night h) }}{\mathrm{ER}_{\mathrm{n}}}$ & $\underset{\text { (light h) }}{\mathrm{ER}_{\mathrm{d}}}$ & $\begin{array}{c}-\mathrm{O}_{2}(\mathrm{mmol} \mathrm{m} \\
\text { Adv./Percol. } \\
(24 \mathrm{~h})^{\mathrm{a}}\end{array}$ & $\begin{array}{l}\left.\mathrm{m}^{-2} \mathrm{~d}^{-1}\right) \\
\mathrm{NPP} \\
\text { (light } \mathrm{h})\end{array}$ & $\begin{array}{c}\text { GPP } \\
\text { (light h) }\end{array}$ & $\begin{array}{l}\text { NEM } \\
(24 \mathrm{~h})\end{array}$ & \multicolumn{2}{|c|}{$\begin{array}{l}\text { Tidal maximum } \\
\text { (daytime } \mathrm{h} \text { ) }\end{array}$} & $\begin{array}{l}\text { Water } \\
\text { level } \\
\max .(\mathrm{m})\end{array}$ & $\begin{array}{c}\text { Inundation } \\
\text { time } \\
\left(\mathrm{h} \mathrm{d}^{-1}\right)\end{array}$ \\
\hline $26 / 09$ & 21.36 & 11.2 & -3.67 & -4.50 & -1.50 & 11.15 & 18.85 & 1.48 & $\begin{array}{l}09: 29 \\
22: 19\end{array}$ & $\begin{array}{l}03: 34 \\
15: 39\end{array}$ & $\begin{array}{l}0.55 \\
0.84\end{array}$ & 12.2 \\
\hline $27 / 09$ & 19.90 & 11.0 & -3.73 & -4.54 & -2.24 & 11.08 & 18.74 & 0.57 & $\begin{array}{l}\text { 10:04 } \\
23: 09\end{array}$ & $\begin{array}{l}04: 09 \\
16: 09\end{array}$ & $\begin{array}{l}0.48 \\
0.48\end{array}$ & 9.7 \\
\hline 28/09 & 3.25 & 7.1 & -4.30 & -1.41 & -1.33 & 2.42 & 5.63 & -4.62 & $\begin{array}{l}10: 31 \\
23: 03\end{array}$ & $\begin{array}{l}04: 28 \\
16: 51\end{array}$ & $\begin{array}{l}-0.14 \\
-0.09\end{array}$ & 0 \\
\hline 29/09 & 9.37 & 8.7 & -4.19 & -2.99 & -1.41 & 6.27 & 11.63 & -2.32 & $\begin{array}{l}10: 31 \\
23: 59\end{array}$ & $\begin{array}{l}05: 11 \\
17: 54\end{array}$ & $\begin{array}{r}-0.11 \\
0.62\end{array}$ & 5.9 \\
\hline $30 / 09$ & 13.06 & 9.6 & -3.98 & -3.74 & -2.87 & 8.30 & 14.68 & -2.30 & $12: 09$ & $\begin{array}{l}06: 19 \\
18: 24\end{array}$ & $\begin{array}{l}0.81 \\
0.9\end{array}$ & 13.5 \\
\hline $01 / 10$ & 11.87 & 10.4 & -3.92 & -4.02 & -1.33 & 8.44 & 15.44 & -0.83 & $\begin{array}{l}00: 59 \\
12: 49\end{array}$ & $\begin{array}{l}06: 24 \\
19: 09\end{array}$ & $\begin{array}{l}0.54 \\
0.47\end{array}$ & 9.5 \\
\hline $02 / 10$ & 17.30 & 10.7 & -3.78 & -3.99 & -1.57 & 9.65 & 16.66 & 0.31 & $\begin{array}{l}01: 29 \\
13: 34\end{array}$ & $\begin{array}{l}07: 24 \\
19: 59\end{array}$ & $\begin{array}{l}0.33 \\
0.33\end{array}$ & 8.2 \\
\hline $03 / 10$ & 6.31 & 9.7 & -3.98 & -2.99 & -2.75 & 5.45 & 11.13 & -4.26 & $\begin{array}{l}01: 54 \\
14: 39\end{array}$ & $\begin{array}{l}07: 59 \\
20: 54\end{array}$ & $\begin{array}{l}0.5 \\
0.25\end{array}$ & 8.5 \\
\hline $04 / 10$ & 2.07 & 5.3 & -4.59 & -0.59 & -3.76 & 1.01 & 2.89 & -7.93 & $\begin{array}{l}02: 39 \\
15: 19\end{array}$ & $\begin{array}{l}08: 59 \\
22: 01\end{array}$ & $\begin{array}{l}0.4 \\
0.41\end{array}$ & 9.7 \\
\hline $\begin{array}{l}\text { Average } \\
\text { SD }\end{array}$ & $\begin{array}{r}11.6 \\
7.0\end{array}$ & $\begin{array}{l}\mathbf{9 . 3} \\
2.0\end{array}$ & $\begin{array}{r}-4.01 \\
0.30\end{array}$ & $\begin{array}{r}-3.20 \\
1.38\end{array}$ & $\begin{array}{r}-2.08 \\
0.87\end{array}$ & $\begin{array}{l}\mathbf{7 . 0 8} \\
3.61\end{array}$ & $\begin{array}{r}\mathbf{1 2 . 8 5} \\
5.60\end{array}$ & $\begin{array}{r}-2.21 \\
3.01\end{array}$ & & & & \\
\hline
\end{tabular}

percolation or convection, the daily benthic $\mathrm{O}_{2}$ uptake was enhanced by $-2.08 \mathrm{mmol} \mathrm{m}^{-2} \mathrm{~d}^{-1}$ and the net ecosystem metabolism (NEM) during the investigation period becomes slightly negative with an average of -2.21 (1.48 to -7.93) $\mathrm{mmol} \mathrm{O}_{2} \mathrm{~m}^{-2} \mathrm{~d}^{-1}$ (Table 2, Fig. 7). The estimate on the relative importance of advection/percolation/convection for the overall $\mathrm{O}_{2}$ consumption rates is, however, conservative. Mainly since the $R_{\mathrm{v}}$ of the deeper sediment layers, given accumulated reduced substances (i.e. iron sulfide, FeS) below the prevailing oxic zone, may be higher than the applied values derived from the surface sediments. Several intertidal and subtidal studies have shown that porewater advection markedly increases OPD, $\mathrm{O}_{2}$ consumption, and aerobic mineralization rates (de Beer et al. 2005, Billerbeck et al. 2006, Werner et al. 2006, Cook et al. 2007, Berg et al. 2013; see also our Table 3). However, these investigations targeted highly permeable sediment, with high interstitial supply of organic matter and $\mathrm{O}_{2}$ facilitated by a well-developed rippled surface topography. At our microtidal study site, characterized by silty sand, the occasional

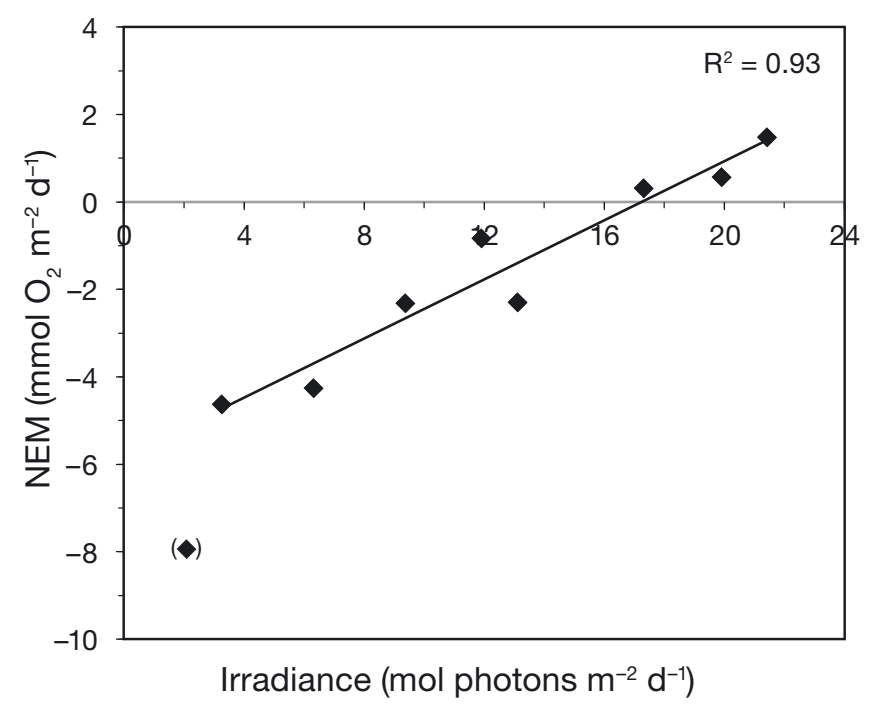

Fig. 7. Relationship between $24 \mathrm{~h}$ time-integrated downwelling irradiance and net ecosystem $\mathrm{O}_{2}$ metabolism (NEM) including tidal advection under calm conditions. The 4 th October (diamond in parentheses) was excluded from the analysis because of stormy conditions prevailing during the first high tide period of the day 
short-term delivery of $\mathrm{O}_{2}$ to greater depth as induced by percolation and advection (convection) cannot to be expected to stimulate aerobic respiration to the same extent. More energetic conditions would presumably have further enhanced the $\mathrm{O}_{2}$ uptake, especially if high flow velocities were combined with wave action and increased sediment resuspension (Vinther et al. 2004). Such conditions were not observed during our study, but high-energy events can have quantitatively large and long-lasting impacts on sediment reoxidation, respiration, and photosynthesis (Jørgensen 1996, Cook et al. 2007, Zetsche et al. 2012).

Besides hydrodynamics, faunal activity can also enhance the $\mathrm{O}_{2}$ exchange and the benthic OPD significantly. About $3 \%$ of the measured $\mathrm{O}_{2}$ microprofiles were visibly affected by macrofaunal activity and bioirrigation, which could have stimulated the benthic $\mathrm{O}_{2}$ consumption (Glud et al. 2003). However, as only 2 sediment cores were recovered for qualitative assessment of fauna occurrence, a precise quantitative assessment of the importance of faunal respiration and irrigation for the overall oxygen budget was not possible. But given the low macrofaunal abundance in these dynamic settings, the faunamediated $\mathrm{O}_{2}$ consumption was probably of minor importance.

\section{Primary production of an intertidal sand flat under low-energy conditions}

The established empirical relationship between solar irradiance and photosynthesis ( $P / E$ curve) (Fig. 5) is based on numerous in situ $\mathrm{O}_{2}$ microprofiles and includes the natural spatial and temporal variability in environmental drivers. It was therefore possible to make a relatively robust estimate of the in situ benthic primary production during the study period. Integrated over the daylight hours of the respective days, the NPP ranged between 1.01 and $11.15 \mathrm{mmol}$ $\mathrm{O}_{2} \mathrm{~m}^{-2} \mathrm{~d}^{-1}$ depending on the light availability, with an average NPP of $7.08 \mathrm{mmol} \mathrm{O}_{2} \mathrm{~m}^{-2} \mathrm{~d}^{-1}$. The ecosystem respiration (ER) in darkness, $\mathrm{ER}_{\mathrm{n}}$, integrated over the number of night hours ranged between -3.67 and $-4.59 \mathrm{mmol} \mathrm{m}^{-2} \mathrm{~d}^{-1}$ with an average of $-4.01 \mathrm{mmol} \mathrm{O}_{2} \mathrm{~m}^{-2} \mathrm{~d}^{-1}$ (Table 2).

To assess gross primary production (GPP) of benthic communities it is commonly assumed that ER remains light-independent (e.g. Spilmont et al. 2007, Denis \& Desreumaux 2009, Glud et al. 2009b). Applying this procedure to our data with GPP $=\mathrm{NPP}+|\mathrm{ER}|$ (where IERI includes respiration in darkness for the depth of the photic zone and respiration below the photic zone as measured during daytime) led to an average GPP of $1.31 \mathrm{mmol} \mathrm{O}_{2} \mathrm{~m}^{-2} \mathrm{~h}^{-1}$. Integrated for the number of daylight hours, the GPP ranged between 2.89 and $18.85 \mathrm{mmol} \mathrm{O}_{2} \mathrm{~m}^{-2} \mathrm{~d}^{-1}$ with an average of $12.85 \mathrm{mmol} \mathrm{O}_{2} \mathrm{~m}^{-2} \mathrm{~d}^{-1}$ (Table 2). However, this value must represent a minimum, given that ER in the photic zone is presumably elevated during daytime (Kühl et al. 1996, Brotas et al. 2003, Glud et al. 2009b) as also indicated by a stimulated daytime respiration $\left(E R_{d}\right)$ below the photic zone (see Figs. 5 \& 6 ). It is difficult to assess how much respiration was elevated within the photic zone during daytime, but previous estimates range between 35 and $80 \%$ (Fenchel \& Glud 2000).

Based on the microprofile measurements obtained during periods without porewater advection, the sediment was, on all days, net autotrophic during daylight, but integration over the diel periods $(24 \mathrm{~h})$ revealed that the system was almost at metabolic balance with a slightly negative NEM of $-0.13 \mathrm{mmol}$ $\mathrm{O}_{2} \mathrm{~m}^{-2} \mathrm{~d}^{-1}$. As outlined above, including high energy periods with porewater advection, NEM became even more heterotrophic with a net $\mathrm{O}_{2}$ exchange rate of $-2.21 \mathrm{mmol} \mathrm{m}^{-2} \mathrm{~d}^{-1}$ (Table 2)

For maintaining balance between benthic heterotrophy and autotrophy during calm periods, a minimum of $\sim 12.0$ mol photons $\mathrm{m}^{-2} \mathrm{~d}^{-1}$ was required. Accounting for advective transport processes (although only occurring $15 \%$ of the time), this value increased to $17.2 \mathrm{~mol}$ photons $\mathrm{m}^{-2} \mathrm{~d}^{-1}$. The close correlation between NEM and the daily integrated incident irradiance demonstrates the importance of light as the main control factor for net system metabolism of intertidal sediments (Fig. 7). In conclusion, the system was almost at metabolic balance during the autumn study period. However, we cannot extrapolate the activity levels beyond the study period, and the communitybased $P / E$ relationship presumably changed across seasons due to differences in light availability, temperature, grazing pressure, and sediment dynamics (Barranguet et al. 1998, Hancke \& Glud 2004, Hubas $\&$ Davoult 2006, Migné et al. 2009). However, the presented data document an extensive spatio-temporal variation in $\mathrm{O}_{2}$ distribution that was mainly related to light availability (i.e. phototrophic activity) during daylight hours. In addition, advection, resuspension, and flow dynamics strongly impacted the benthic activity. Macrofauna activity and temperature dynamics during the study period were presumably of minor importance for benthic $\mathrm{O}_{2}$ exchange. However, all together the data highlight the importance of applying non-invasive measuring approaches to correctly assess in situ productivity of intertidal systems. 


\section{Cross-study comparisons of NEM in intertidal sediments}

Despite the importance of tidal environments for production and degradation of organic material, their overall trophic status is poorly established (Denis \& Desreumaux 2009, Klaassen \& Spilmont 2012). However, provided that in situ dynamics are taken into account, the net turnover of organic carbon can be robustly assessed by quantifying NEM via either $\mathrm{O}_{2}$ or $\mathrm{CO}_{2}$ exchange as integrated on a $24 \mathrm{~h}$ basis (Staehr et al. 2012). This provides an integrated measure of phototrophic and heterotrophic activity, including re-oxidation of reduced end-products from quantitatively important anaerobic metabolic pathways (Fenchel \& Glud 2000). However, a cross-study comparison is complicated by the use of different measuring procedures and often an insufficient amount of information for calculating NEM.

Here, we have tried to standardize calculations from available studies to provide such cross-study analysis of ER, NPP, GPP, and most importantly NEM of different temperate intertidal systems (Table 3). We analysed data from 12 comparable studies of tidally influenced sediments, of which 7 were conducted during the autumn (Table 3, values are given in $\mathrm{O}_{2}$ concentrations). The ER varied more than 100fold, from $-0.06 \mathrm{mmol} \mathrm{m}^{-2} \mathrm{~h}^{-1}$ in fine sandy sediments (Roscoff Aber Bay, France) to approx. $-7.5 \mathrm{mmol} \mathrm{m}^{-2}$ $\mathrm{h}^{-1}$ in permeable sandy sediments (Spiekeroog, Sylt, Germany). Clearly, the ER is highly dependent on advective porewater transport and the ability of the permeable sediments to act as a biocatalytic filter (Huettel et al. 2003). However, maintaining an advective supply of organic material and $\mathrm{O}_{2}$ for elevated respiratory activity requires frequent resetting of the sediment by major resuspension/storm events to avoid clogging of the pore space, which otherwise would reduce sediment permeability (Zetsche et al. 2011, 2012). Nevertheless, the available studies in highly permeable settings (Sylt, Spiekeroog; Table 3) only exhibited relatively low seasonal variability, with an average $( \pm \mathrm{SD}) \mathrm{NPP}$ of $2.13 \pm 1.26 \mathrm{mmol} \mathrm{m}^{-2}$ $\mathrm{h}^{-1}$. In contrast, a megatidal exposed sandy beach at Wimereux (Spilmont et al. 2005, not included in Table 3) was characterized by a relatively low benthic metabolism with high variability during a $3 \mathrm{yr}$ survey (GPP: $1.45 \pm 3.40 \mathrm{mmol} \mathrm{m}^{-2} \mathrm{~h}^{-1}$; ER: $0.14 \pm$ $0.16 \mathrm{mmol} \mathrm{m}^{-2} \mathrm{~h}^{-1}$; mean $\pm \mathrm{SD}$ ), highly depending on meteorological conditions. Calm conditions favoured microalgae blooms while windy periods favoured heterogeneous deposition of planktonic detrital material (foam) causing short events of maximum metabolic rates with a net productivity of up to 17.81 $\mathrm{mmol} \mathrm{O}_{2} \mathrm{~m}^{-2} \mathrm{~h}^{-1}$ or a net consumption of $-1 \mathrm{mmol} \mathrm{O}_{2}$ $\mathrm{m}^{-2} \mathrm{~h}^{-1}$ (not shown). The impact on the local carbon budget was low, but is assumed to be significant at a larger spatial scale.

In low-energy intertidal systems with muddy and presumably diffusion-controlled sediments, the average ER amounted to $-0.91 \mathrm{mmol} \mathrm{m}^{-2} \mathrm{~h}^{-1}$ ( 7 studies, Table 3). Most of these studies were conducted during autumn and exhibited an average daytime NPP rate of $0.61 \mathrm{mmol} \mathrm{m}^{-2} \mathrm{~h}^{-1}$ (5 studies). The single observations ranged between -3.80 and $9.36 \mathrm{mmol} \mathrm{m}^{-2}$ $\mathrm{h}^{-1}$. However, a few long-term studies indicated considerable variability during specific days and also between days as well as a seasonal maximum in primary production during spring and summer (Canche and Tagus estuaries, Table 3 ).

All sites exhibited considerable GPP, ranging from $0.49 \mathrm{mmol} \mathrm{m}^{-2} \mathrm{~h}^{-1}$ at Neuharlinger Siel (Germany) (under light limitation during high tide) to $24.3 \mathrm{mmol}$ $\mathrm{m}^{-2} \mathrm{~h}^{-1}$ in the Tagus Estuary (Portugal) on a bright summer day. Overall, the few available studies did not indicate any specific relation between GPP and sediment texture or any seasonality. Given the published information, NEM could only be extracted from 6 of the available studies and ranged from $-140 \mathrm{mmol} \mathrm{m}^{-2}$ $\mathrm{d}^{-1}$ in the highly permeable sandy sediments at Sylt (Germany) (Table 3) to $9.71 \mathrm{mmol} \mathrm{m}^{-2} \mathrm{~d}^{-1}$ at a mudflat of the Seine Estuary (France). The ER, NPP, GPP, as well as NEM derived for our microtidal area in Skallingen exhibit net-heterotrophic conditions and fall well within the broad span of rates found in intertidal in situ studies conducted under calm conditions during autumn.

Generally, our review of relevant studies (Table 3) indicated net heterotrophy, with the exception being sandy sites under low-energy conditions in the Roscoff Aber Bay (France), where sediments were found to be autotrophic throughout the year (Hubas \& Davoult 2006). Overall, the available data thereby suggest that despite considerable primary production, tidally influenced sediments appear to be net heterotrophic with an average NEM value reaching $-105 \mathrm{mmol} \mathrm{m}^{-2} \mathrm{~d}^{-1}$ for highly permeable sands and $-3.00 \mathrm{mmol} \mathrm{m} \mathrm{m}^{-2} \mathrm{~d}^{-1}$ for sediments under low-energy conditions in autumn. The heterotrophic activity must be sustained by external organic matter delivered by tidal and riverine inflow and/or local primary production from the preceding summer months. However, it must be emphasized that cross-seasonal extrapolation is problematic. Most available studies poorly resolve seasonal dynamics and tend not to include high energetic periods during storms or floods. Indeed, previous 


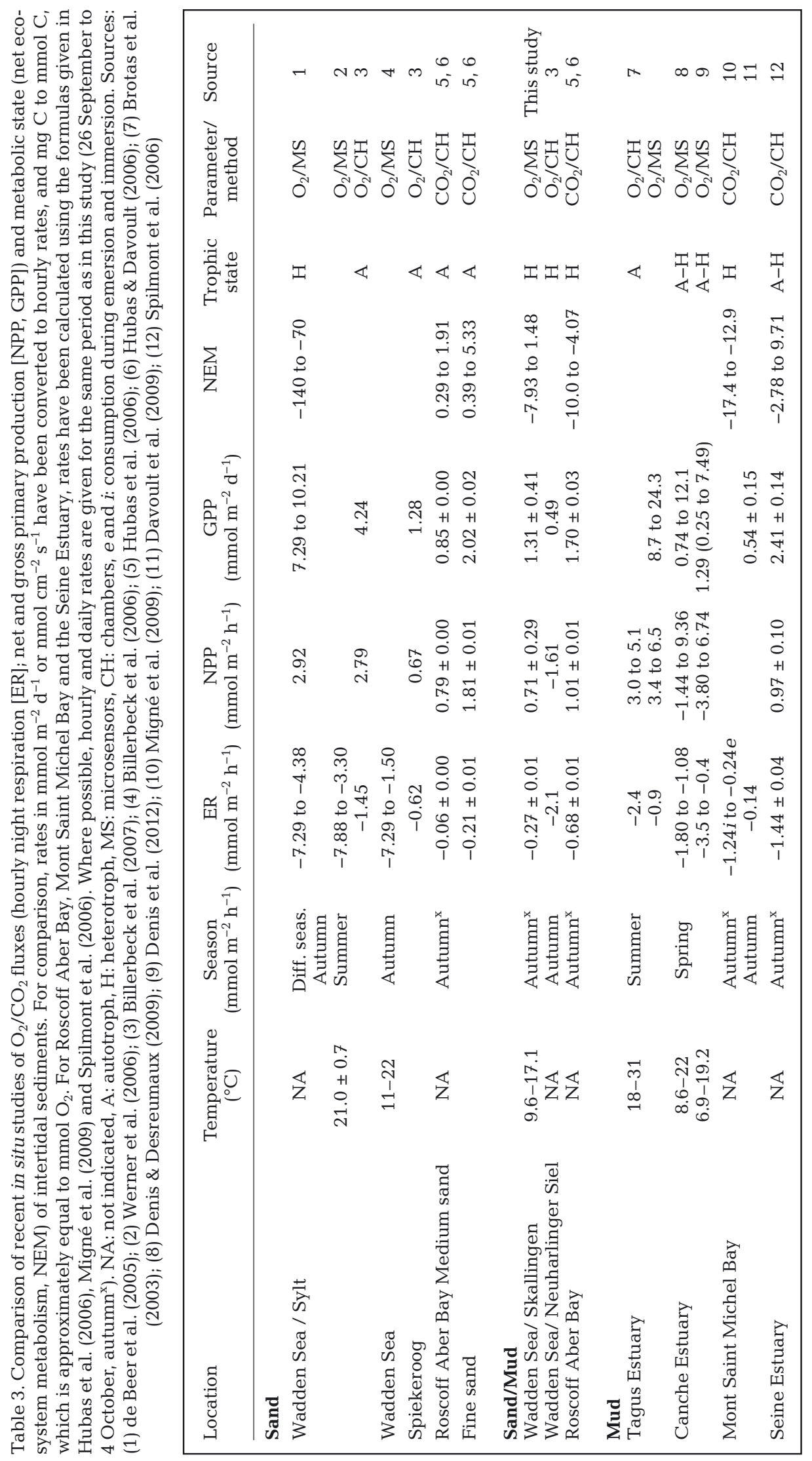

studies have concluded that in many cases it is difficult to resolve if intertidal settings are sources or sinks for $\mathrm{C}$ and nutrients (e.g. Middelburg et al. 1996, Cook et al. 2004, Cai 2011, Klaassen \& Spilmont 2012). More long-term and seasonal non-invasive in situ investigations are required to resolve this question. Recently, aquatic eddy correlation (AEC, e.g. Berg \& Huettel 2008, McGinnis et al. 2014) has proven itself as a very powerful, non-invasive technique for resolving benthic $\mathrm{O}_{2}$ exchange and metabolism in challenging coastal environments (e.g. Glud et al. 2010, Attard et al. 2014, Long et al. 2015). The approach, however, will only work during inundation, but combined application of AEC and continuous autonomous in situ microprofiling measurements, as realized here, might represent an ideal procedure for resolving NEM in dynamic intertidal settings and to assess the importance of such environments for marine carbon cycling in general.

Acknowledgements. This study was conducted within the framework of the project 'Oxygen availability controlling the dynamics of buried organic carbon pools and greenhouse gas emissions' financed by the Danish Council for Independent Research (FNU). E.W. and R.N.G. were additionally supported by the FNU project 0602-02276B, the Commission for Scientific Research in Greenland (KVUG, GCRC6507), the UK National Environmental Research Council (NERC, NE/F1018612/1 and the European Research Council (ERC-adG-2014669947 HADES-ERC). We thank Anni Glud for providing the sensors and introduction in sensor maintenance, Paul Christiansen, Hanna Ferdinand, Mikkel Fruergaard and Lasse Kirkegaard for technical assistance and help during field work. We appreciate the constructive anonymous reviews that helped us improving the manuscript. 


\section{LITERATURE CITED}

Andersen TJ (2001) Seasonal variations in erodibility of two temperate, microtidal mudflats. Estuar Coast Shelf Sci $53: 1-12$

Andersen TJ, Lanuru M, van Bernem C, Pejrup M, Riethmueller R (2010) Erodibility of a mixed mudflat dominated by microphytobenthos and Cerastoderma edule, East Frisian Wadden Sea, Germany. Estuar Coast Shelf Sci 87:197-206

Anschutz P, Smith T, Mouret A, Deborde J, Bujan S, Poirier D, Lecroart P (2009) Tidal sands as biogeochemical reactors. Estuar Coast Shelf Sci 84:84-90

Attard KM, Glud RN, McGinnis DF, Rysgaard S (2014) Seasonal rates of benthic primary production in a Greenland fjord measured by aquatic eddy correlation. Limnol Oceanogr 59:1555-1569

Barranguet C, Kromkamp J, Peene J (1998) Factors controlling primary production and photosynthetic characteristics of intertidal microphytobenthos. Mar Ecol Prog Ser 173:117-126

* Bartoli M, Nizzoli D, Viaroli P (2003) Microphytobenthos activity and fluxes at the sediment-water interface: interactions and spatial variability. Aquat Ecol 37: 341-349

Berg P, Huettel M (2008) Monitoring the seafloor using the non-invasive eddy correlation technique: integrated benthic exchange dynamics. Oceanography (Wash DC) 21:164-167

Berg P, Risgaard-Petersen N, Rysgaard S (1998) Interpretation of measured profiles in sediment pore water. Limnol Oceanogr 43:1500-1510

Berg P, Long MH, Huettel M, Rheuban JE and others (2013) Eddy correlation measurements of oxygen fluxes in permeable sediments exposed to varying current flow and light. Limnol Oceanogr 58:1329-1343

Billerbeck M, Werner U, Polerecky L, Walpersdorf E, de Beer D, Huettel M (2006) Surficial and deep pore water circulation governs spatial and temporal scales of nutrient recycling in intertidal sand flat sediment. Mar Ecol Prog Ser 326:61-76

Billerbeck M, Røy H, Bosselmann K, Huettel M (2007) Benthic photosynthesis in submerged Wadden Sea intertidal flats. Estuar Coast Shelf Sci 71:704-716

Brotas V, Risgaard-Petersen N, Serodio J, Ottosen L, Dalsgaard T, Ribeiro L (2003) In situ measurements of photosynthetic activity and respiration of intertidal benthic microalgal communities undergoing vertical migration. Ophelia 57:13-26

Cahoon LB (1999) The role of benthic microalgae in neritic ecosystems. Oceanogr Mar Biol Annu Rev 37:47-86

Cai WJ (2011) Estuarine and coastal ocean carbon paradox: $\mathrm{CO}_{2}$ sinks or sites of terrestrial carbon incineration? Annu Rev Mar Sci 3:123-145

Cammen LM (1991) Annual bacterial production in relation to benthic microalgal production and sediment oxygen uptake in an intertidal sandflat and an intertidal mudflat. Mar Ecol Prog Ser 71:13-25

Cook PLM, Revill AT, Clementson LA, Volkman JK (2004) Carbon and nitrogen cycling on intertidal mudflats of a temperate Australian estuary. III. Sources of organic matter. Mar Ecol Prog Ser 280:55-72

Cook PLM, Wenzhöfer F, Glud RN, Janssen F, Hüttel M (2007) Benthic solute exchange and carbon mineralization in two shallow subtidal sandy sediments: impact of advective pore-water exchange. Limnol Oceanogr 52: 1943-1963

* Davoult D, Migné A, Créach A, Gevaert F, Hubas C, Spilmont N, Boucher G (2009) Spatio-temporal variability of intertidal benthic primary production and respiration in the western part of the Mont Saint-Michel Bay (Western English Channel, France). Hydrobiologia 620:163-172

* de Beer D, Wenzhöfer F, Ferdelman TG, Boehme SE and others (2005) Transport and mineralization rates in North Sea sandy intertidal sediments, Sylt-Rømø Basin, Wadden Sea. Limnol Oceanogr 50:113-127

* de Brouwer JFC, Stal LJ (2001) Short-term dynamics in microphytobenthos distribution and associated extracellular carbohydrates in surface sediments of an intertidal mudflat. Mar Ecol Prog Ser 218:33-44

De Wit R, Jonkers HM, van den Ende FP, van Gemerden H (1989) In situ fluctuations of oxygen and sulphide in marine microbial sediment ecosystems. Neth J Sea Res 23: 271-281

*Denis L, Desreumaux PE (2009) Short-term variability of intertidal microphytobenthic production using an oxygen profiling system. Mar Freshw Res 60:712-726

* Denis L, Gevaert F, Spilmont N (2012) Microphytobenthic production estimated by in situ oxygen microprofiling: short-term dynamics and carbon budget implications. J Soils Sediments 12:1517-1529

*Du GY, Son M, An S, Chung IK (2010) Temporal variation in the distribution of microphytobenthos in intertidal flats of the Nakdong River estuary, Korea. Estuar Coast Shelf Sci 86:62-70

Ehrenhauss S, Huettel M (2004) Advective transport and decomposition of chain-forming planktonic diatoms in permeable sediments. J Sea Res 52:179-197

* Ehrenhauss S, Witte U, Bühring SI, Huettel M (2004) Effect of advective pore water transport on distribution and degradation of diatoms in permeable North Sea sediments. Mar Ecol Prog Ser 271:99-111

Fenchel T, Glud RN (2000) Benthic primary production and $\mathrm{O}_{2}-\mathrm{CO}_{2}$ dynamics in a shallow water sediment: spatial and temporal activity. Ophelia 53:159-171

Forster S, Bobertz B, Bohling B (2003) Permeability of sands in the coastal areas of the southern Baltic Sea: mapping a grain-size related sediment property. Aquat Geochem 9: 171-190

Glud RN, Jensen K, Revsbech NP (1995) Diffusivity in surficial sediments and benthic mats determined by use of a combined $\mathrm{N}_{2} \mathrm{O}-\mathrm{O}_{2}$ microsensor. Geochim Cosmochim Acta 59:231-237

Glud RN, Gundersen JK, Røy H, Jørgensen BB (2003) Seasonal dynamics of benthic $\mathrm{O}_{2}$ uptake in a semienclosed bay: importance of diffusion and faunal activity. Limnol Oceanogr 48:1265-1276

* Glud RN, Stahl H, Berg P, Wenzhöfer F, Oguri K, Kitazato H (2009a) In situ microscale variation in distribution and consumption of $\mathrm{O}_{2}$ : a case study from a deep ocean margin sediment (Sagami Bay, Japan). Limnol Oceanogr 54:1-12

Glud RN, Woelfel J, Karsten U, Kühl M, Rysgaard S (2009b) Benthic microalgal production in the Arctic: applied methods and status of the current database. Bot Mar 52:559-571

F Glud RN, Berg P, Hume A, Batty P, Blicher ME, Lennert K, Rysgaard S (2010) Benthic $\mathrm{O}_{2}$ exchange across hardbottom substrates quantified by eddy correlation in a sub-Arctic fjord. Mar Ecol Prog Ser 417:1-12

Grasshoff K, Kremling K, Ehrhardt M (1999) Methods of seawater analysis. Wiley-VCH, Weinheim 
Gundersen JK, Glud RN, Jørgensen BB (1995) Havbundens iltomsætning. Havforskning fra Miljøstyrelsen, Hav-90. Faglig Rapport No. 57. Environmental Protection Agency, Copenhagen

Hancke K, Glud RN (2004) Temperature effects on respiration and photosynthesis in three diatom-dominated benthic communities. Aquat Microb Ecol 37:265-281

Hubas C, Davoult D (2006) Does seasonal proliferation of Enteromorpha sp. affect the annual benthic metabolism of a small macrotidal estuary? (Roscoff Aber Bay, France). Estuar Coast Shelf Sci 70:287-296

Hubas C, Davoult D, Cariou T, Artigas LF (2006) Factors controlling benthic metabolism during low tide along a granulometric gradient in an intertidal bay (Roscoff Aber Bay, France). Mar Ecol Prog Ser 316:53-68

Huettel M, Røy H, Precht E, Ehrenhauss S (2003) Hydrodynamical impact on biogeochemical processes in aquatic sediments. Hydrobiologia 494:231-236

Iversen N, Jørgensen BB (1993) Diffusion coefficients of sulfate and methane in marine sediments: influence of porosity. Geochim Cosmochim Acta 57:571-578

Jørgensen BB (1996) Material flux in the sediment. In: Jørgensen BB, Richardson K (eds) Eutrophication in coastal marine ecosystems. American Geophysical Union, Washington, DC, p 115-136

Jørgensen BB, Revsbech NP (1985) Diffusive boundary layers and the oxygen uptake of sediment and detritus. Limnol Oceanogr 30:111-122

Jørgensen BB, Glud RN, Holby O (2005) Oxygen distribution and bioirrigation in Arctic fjord sediments (Svalbard, Barents Sea). Mar Ecol Prog Ser 292:85-95

Klaassen W, Spilmont N (2012) Inter-annual variability of $\mathrm{CO}_{2}$ exchanges between an emersed tidal flat and the atmosphere. Estuar Coast Shelf Sci 100:18-25

Klute A, Dirksen C (1986) Hydraulic conductivity and diffusivity: laboratory methods. In: Klute A (ed) Methods of soil analysis, Part 1. Physical and mineralogical methods. American Society of Agronomy, Madison, WI, p 687-700

Kühl M (2005) Optical microsensors for analysis of microbial communities. Methods Enzymol 397:166-199

Kühl M, Glud RN, Ploug H, Ramsing NB (1996) Microenvironmental control of photosynthesis and photosynthesiscoupled respiration in an epilithic cyanobacterial biofilm. J Phycol 32:799-812

Kühl M, Lassen C, Revsbech NP (1997) A simple light meter for measurements of PAR (400 to $700 \mathrm{~nm}$ ) with fiber-optic microprobes: application for $P$ vs $E_{0}(\mathrm{PAR})$ measurements in a microbial mat. Aquat Microb Ecol 13:197-207

Li YH, Gregory S (1974) Diffusion of ions in sea water and deep sea sediments. Geochim Cosmochim Acta 88: 708-714

Long MH, Berg P, McGlathery KJ, Zieman JC (2015) Subtropical seagrass ecosystem metabolism measured by eddy covariance. Mar Ecol Prog Ser 529:75-90

* Lorenzen CJ (1967) Determination of chlorophyll and pheo-pigments: spectrophotometric equations. Limnol Oceanogr 12:343-346

Lotze HK, Reise K, Worm B, van Beusekom J and others (2005) Human transformations of the Wadden Sea ecosystem through time: a synthesis. Helgol Mar Res 59: 84-95

MacIntyre HL, Geider RJ, Miller DC (1996) Microphytobenthos: the ecological role of the 'Secret Garden' of unvegetated, shallow water marine habitats. I. Distribution, abundance and primary production. Estuaries 19:186-201
McGinnis DF, Sommer S, Lorke A, Glud RN, Linke P (2014) Quantifying tidally-driven benthic oxygen exchange across permeable sediments: an aquatic eddy correlation study. J Geophys Res Oceans 119:6918-6932

*Middelburg JJ, Klaver G, Nieuwenhuize J, Wielemaker A, de Haas W, Vlug T, van der Nat JFWA (1996) Organic matter mineralization in intertidal sediments along an estuarine gradient. Mar Ecol Prog Ser 132: 157-168

* Middelburg JJ, Barranguet C, Boschker HTS, Herman PMJ, Moens T, Heip CHR (2000) The fate of intertidal microphytobenthos carbon: an in situ ${ }^{13} \mathrm{C}$-labeling study. Limnol Oceanogr 45:1224-1234

Migné A, Spilmont N, Boucher G, Denis L and others (2009) Annual budget of benthic production in Mont SaintMichel Bay considering cloudiness, microphytobenthos migration, and variability of respiration rates with tidal conditions. Cont Shelf Res 29:2280-2285

* Paterson DM (1989) Short-term changes in the erodibility of intertidal cohesive sediments related to the migratory behaviour of epipelic diatoms. Limnol Oceanogr 34: 223-234

Paterson DM, Hagerthey SE (2001) Microphytobenthos in contrasting coastal ecosystems: biology and dynamics. In: Reise K (ed) Ecological comparisons of sedimentary shores. Ecological Studies, Vol 151. Springer-Verlag, Berlin, p 105-125

Platt T, Gallegos CL, Harrison WG (1980) Photoinhibition of photosynthesis in natural assemblages of marine phytoplankton. J Mar Res 38:687-701

Reise K (2005) Coast of change: habitat loss and transformations in the Wadden Sea. Helgol Mar Res 59:9-21

Revsbech NP (1989) An oxygen microelectrode with a guard cathode. Limnol Oceanogr 34:474-478

* Rickelt LF, Lichtenberg M, Trampe E, Kühl M (2016) Fiberoptic probes for small-scale measurements of scalar irradiance. Photochem Photobiol 92:331-342

* Risgaard-Petersen N (2003) Coupled nitrification-denitrification in autotrophic and heterotrophic estuarine sediments: on the influence of benthic microalgae. Limnol Oceanogr 48:93-105

* Spilmont N, Migné A, Lefebvre A, Artigas LF, Rauch M, Davoult D (2005) Temporal variability of intertidal benthic metabolism under emersed conditions in an exposed sandy beach (Wimereux, eastern English Channel, France). J Sea Res 53:161-167

* Spilmont N, Davoult D, Migné A (2006) Benthic primary production during emersion: in situ measurements and potential primary production in the Seine Estuary (English Channel, France). Mar Pollut Bull 53:49-55

พ Spilmont N, Migné A, Seuront L, Davoult D (2007) Shortterm variability of intertidal benthic community production during emersion and the implication in annual budget calculation. Mar Ecol Prog Ser 333:95-101

* Staehr PA, Testa JM, Kemp WM, Cole JJ, Sand-Jensen K, Smith SV (2012) The metabolism of aquatic ecosystems: history, applications, and future challenges. Aquat Sci 74:15-29

K Sundbäck K, Miles A, Göransson E (2000) Nitrogen fluxes, denitrification and the role of microphytobenthos in microtidal shallow-water sediments: an annual study. Mar Ecol Prog Ser 200:59-76

Underwood GJC, Kromkamp J (1999) Primary production by phytoplankton and microphytobenthos in estuaries. Adv Ecol Res 29:93-153 
Vinther N, Christiansen C, Bartholdy J, Sørensen C, LundHansen LC (2004) Sediment transport across a tidal divide in the Danish Wadden Sea. Geogr Tidsskr 104:71-86

Werner U, Billerbeck M, Polerecky L, Franke U, Huettel M, Van Beusekom JEE, de Beer D (2006) Spatial and temporal pattern of mineralization rates and oxygen distribution in a permeable intertidal sandflat (Sylt, Germany). Limnol Oceanogr 51:2549-2563

Westall F, Rincé Y (1994) Biofilms, microbial mats and

Editorial responsibility: Erik Kristensen, Odense, Denmark microbe-particle interactions: electron microscope observations from diatomaceous sediments. Sedimentology 41:147-162

K Zetsche E, Paterson DM, Lumsdon DG, Witte U (2011) Temporal variation in the sediment permeability of an intertidal sandflat. Mar Ecol Prog Ser 441:49-63

* Zetsche E, Bulling MT, Witte U (2012) Permeability of intertidal sandflats: impact of temporal variability on sediment metabolism. Cont Shelf Res 42:41-50

Submitted: July 21, 2016; Accepted: December 13, 2016 Proofs received from author(s): February 12, 2017 